Review Article COVID-19 - Special Issue

\title{
Zoonotic spillover: Understanding basic aspects for better prevention
}

\author{
Joel Henrique Ellwanger ${ }^{1}$ (D) and José Artur Bogo Chies $^{1}$ (i) \\ ${ }^{1}$ Universidade Federal do Rio Grande do Sul, Departamento de Genética, Programa de Pós-Graduação em \\ Genética e Biologia Molecular, Laboratório de Imunobiologia e Imunogenética, Porto Alegre, RS, Brazil.
}

\begin{abstract}
The transmission of pathogens from wild animals to humans is called "zoonotic spillover". Most human infectious diseases $(60-75 \%)$ are derived from pathogens that originally circulated in non-human animal species. This demonstrates that spillover has a fundamental role in the emergence of new human infectious diseases. Understanding the factors that facilitate the transmission of pathogens from wild animals to humans is essential to establish strategies focused on the reduction of the frequency of spillover events. In this context, this article describes the basic aspects of zoonotic spillover and the main factors involved in spillover events, considering the role of the inter-species interactions, phylogenetic distance between host species, environmental drivers, and specific characteristics of the pathogens, animals, and humans. As an example, the factors involved in the emergence of Severe Acute Respiratory Syndrome Coronavirus 2 (SARS-CoV-2) pandemic are discussed, indicating what can be learned from this public health emergency, and what can be applied to the Brazilian scenario. Finally, this article discusses actions to prevent or reduce the frequency of zoonotic spillover events.
\end{abstract}

Keywords: Zoonosis, spillover, pathogen, infectious diseases, COVID-19.

Received: September 29, 2020; Accepted: April 5, 2021.

\section{Introduction}

Outbreaks and epidemics are frequent events in human history. Some of them take on pandemic proportions, reaching populations on different continents. As a matter of fact, several pathogens that infect humans are derived from other animal species. Conservative estimates indicate that around $60 \%$ of all emerging human infectious diseases have a zoonotic origin (Woolhouse and Gowtage-Sequeria, 2005; Jones et al., 2008). Other estimates suggest that this percentage reaches up to $75 \%$ (Taylor et al., 2001). Regardless of the differences between these estimates, it is evident that most human infectious diseases have a zoonotic origin. In other words, these diseases originate from pathogens that were transmitted from nonhuman animals to humans, through a process known as zoonotic spillover. For instance, HIV was introduced in the human population from non-human primates in the 1920s or even before, and the AIDS pandemic emerged between the 1960s and 1990s, subsequently rapidly spreading throughout the world (Gilbert et al., 2007; Faria et al., 2014; Worobey et al., 2016; Gryseels et al., 2020).

The Severe Acute Respiratory Syndrome Coronavirus (SARS-CoV) emerged in humans in 2002/2003 and the Middle East Respiratory Syndrome Coronavirus (MERS-CoV) in 2012. Both these coronaviruses were likely derived from viral strains found in bats. Palm civets and dromedary camels potentially acted as intermediate hosts for the introduction of the SARS-

Send correspondence to José Artur Bogo Chies. Universidade Federal do Rio Grande do Sul, Departamento de Genética, Programa de Pós-Graduação em Genética e Biologia Molecular, Laboratório de Imunobiologia e Imunogenética, Av. Bento Gonçalves, 9500, Campus do Vale, 91501-970, Porto Alegre, RS, Brazil. E-mail: jabchies@ terra.com.br.
$\mathrm{CoV}$ and MERS-CoV in the human population, respectively (de Wit et al., 2016). In late 2019, a new respiratory disease called Coronavirus Disease 19 (COVID-19) emerged in China. The disease is caused by the Severe Acute Respiratory Syndrome Coronavirus 2 (SARS-CoV-2), an RNA virus belonging to the Coronaviridae family, genus Betacoronavirus. This new human coronavirus has spread rapidly between different countries, causing the COVID-19 pandemic (Wu et al., 2020).

Activities and factors that increase the interaction of humans with different animal species and pathogens they host, which include handling, poaching, and consumption of meat from wild animals and derived products, are associated with increased risk of spillover events (Kurpiers et al., 2016; Ellwanger et al., 2020). For example, the HIV spillover from non-human primates to humans occurred through the manipulation of meat of primates probably slaughtered for human consumption (Hahn et al., 2000). In addition to serving as a source of food, in many countries, wild animals and their products are also sold in live animal markets ("wet markets") for medicinal purposes or cultural practices, as souvenirs, pets, among other finalities. These markets contribute significantly to the interaction of humans with different species and new pathogens. In those places where different species are confined, pathogens can be transmitted not only through contact with meat, blood and other biofluids, but also through aerosols and contaminated surfaces (Brown, 2004; Lo et al., 2019; Aguirre et al., 2020; Wassenaar and Zou, 2020). Activities in sylvatic environments, such as deforestation and construction of human settlements in forest areas, also increase the interaction between humans and different species and for this reason are important drivers of spillover events. The accelerated growth of the world population and the increased loss of global biodiversity, as a result of human activity, suggest that spillover events will become more and more frequent (Ellwanger et al., 2020). 
It is necessary to understand which factors facilitate spillover events, in order to apply actions to reduce the frequency of transmission of pathogens from wild animals to humans, minimizing the risk of new outbreaks, epidemics, and pandemics. In this context, the first part of this review describes the basic aspects of zoonotic spillover and the main factors involved in spillover events, considering characteristics of hosts (humans and other animal species), environment, and pathogens. Also, the factors and the potential animal species involved in the emergence of the SARS-CoV-2 pandemic are discussed, aiming to consolidate lessons that can be applied to the Brazilian scenario. Finally, this article describes actions to prevent or reduce the frequency of zoonotic spillover events. In sum, the objective of this article is to review the basic aspects of zoonotic spillover from a One Health perspective, covering the several aspects associated to the environment, humans, pathogens, and non-human animals.

\section{Methodological notes}

This article is structured as a narrative review. The manuscript was written based on searches in the databases PubMed/MEDLINE (https://pubmed.ncbi.nlm.nih.gov/), SciELO (https://scielo.org/) and Google Scholar (https:// scholar.google.com.br/), using the terms "spillover", "zoonotic spillover", "pathogen spillover", "host jump”, "cross-species transmission" and "zoonotic transfer", considering articles published in English and without restriction for year of publication. The articles that described basic and conceptual aspects regarding zoonotic spillover were included in this review. In addition to original articles, theoretical works describing discussions or concepts relevant to the topics covered in the review were also included. From this initial selection of key papers, we complemented the article with discussions on specific topics based on the selection of papers in a more specific way, with targeted searches using terms related to topics of interest (e.g., MERS-CoV, HIV, SARS-CoV-2, COVID-19), and also using the electronic library on zoonotic spillover and related content maintained by the authors in recent years. Of note, although this article was written during the COVID-19 pandemic, we bring also examples unrelated to SARS-CoV-2/COVID-19 since the topics discussed here apply not only to the current pandemic, but also to outbreaks, epidemics and pandemics occurred in the past and those that will certainly happen in the future, on a smaller or larger scale. This review was written with the aim of being accessible to a wide audience of readers, from different research fields. For that reason, basic and introductory aspects of zoonotic spillover are mentioned. This is not an exhaustive review of the topic.

\section{Basic aspects of zoonotic spillover}

The transmission of pathogens between different species, the crossing of species barriers, is an ecological phenomenon known as "host jump", "cross-species transmission", "zoonotic transfer", "pathogen spillover", or "zoonotic spillover" (Lu et al., 2015; Plowright et al., 2017; Knetsch et al., 2018; Becker et al., 2019). Specifically, "spillover" can be defined as the "cross-species transmission of a parasite into a host population not previously infected" (Wells and Clark, 2019). Usually, spillover refers to the cross-species transmission of pathogens from wildlife (vertebrate animals) to humans (Plowright et al., 2017; Wells and Clark, 2019). The transmission of a pathogen from humans to wildlife (reverse zoonosis), by direct contact between species or mediated by vectors, can be called "spillback" (Weaver, 2013; Hendy et al., 2020; Olival et al., 2020). Finally, "horizontal virus transfer" is a term that can be used to describe the transmission (regardless of direction) of viruses between different species, including viral transmission between organisms of different biological kingdoms (Dolja and Koonin, 2018).

Spillover is a complex and multifactorial phenomenon, involving aspects associated with the hosts, microorganisms and the environment. The risks of a spillover event occurring will be primarily influenced by the prevalence and intensity of infection in reservoir hosts, usually non-human animals from wild environments or farms. The distribution and density of infected hosts in a given environment is also a determining factor for the spillover risk (Plowright et al., 2017). The prevalence and intensity of infection in reservoir hosts are relevant because these factors determine the pathogen load in such species and the patterns of pathogen shedding. Both factors are influenced by the immunological conditions of the hosts, the interactions between different species (e.g., prey-predator interactions, habitat sharing) and environmental aspects (e.g., characteristics of ecosystem boundaries, presence/absence of environmental degradation). The pathogen load observed in reservoir hosts influences the amount of pathogens that will be excreted in the environment (e.g., through feces) or will be found in the meat and biofluids of these animals. Of note, the characteristics of pathogens also influence the risk of spillover events since they determine the viability of the pathogen in the environment and its ability to be transmitted between different hosts or vectors (Plowright et al., 2017; Becker et al., 2019; Borremans et al., 2019).

Ecological and intrinsic factors related to the microorganisms influence the risk of spillover events even before the interaction with humans, since other animals and pathogens could also be involved in the process. Then, the frequency of human contact with animals as well as the dose and route of exposure to the pathogens will modulate the risk of spillover. Looking specifically at human related factors, biological (e.g., genetics, immune status, physical state of skin and mucous membranes) and social aspects (e.g., cultural practices, eating habits, housing characteristics) will affect the mode, intensity and frequency of interactions with different host species or vectors (Plowright et al., 2017; Becker et al., 2019; Borremans et al., 2019). Indeed, there are several barriers and factors between wildlife organisms and humans that hinder the transmission of pathogens from wild animals to the human population (Figure 1). The same applies to pathogens transmitted from livestock animals to humans. These barriers must be overcomed in zoonotic spillovers, and will be discussed in the next section.

Spillover generally involves (I) a "source host": species responsible for shedding the pathogen; (II) a "recipient host": a species that is infected by the pathogen from a different host; and (III) a "bridge/intermediate host": a host species that acts as a bridge or link in the transfer of the pathogen 


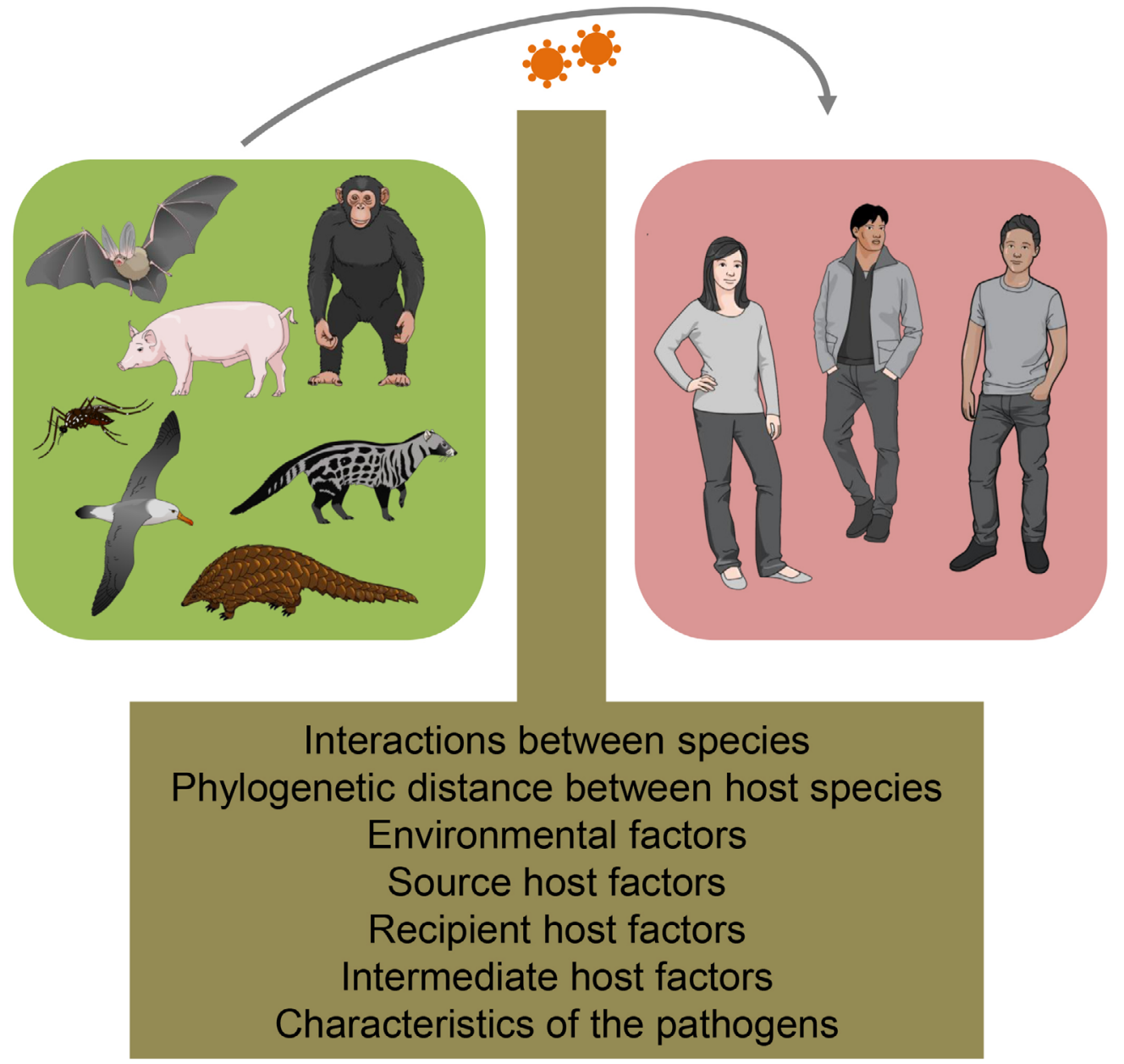

Figure 1 - Factors between wildlife, livestock animals and humans. The intensity and frequency of interactions between species, the phylogenetic distance between host species, characteristics of the pathogens, source host-associated factors, recipient host-associated factors, environmental factors, and intermediate host-associated factors (when this particular host is present) can hinder or facilitate the transmission of pathogens from wild animals/ livestock to the human population. The zoonotic spillover occurs when these factors are favorable to the pathogen, allowing the crossing of barriers between species. This figure was created using Mind the Graph illustrations (available at www.mindthegraph.com).

between species. The intermediate host can be a vertebrate host or an invertebrate vector, such as a mosquito. The intermediate host may or may not be present in the spillover event (Borremans et al., 2019). Many pathogens survive outside the host without losing viability and transmissibility, and therefore the environment can act as an intermediary in the transmission of pathogens between different species. In other words, exposure of the recipient host to the new pathogen can occur either directly (e.g., through an animal bite or contact with contaminated secretion/blood) or indirectly (e.g., through a vector, or contact with contaminated feces or a surface containing the microorganism) (Wolfe et al., 2005; Kurpiers et al., 2016; Borremans et al., 2019). Figure 2 shows schematically the main ways that new pathogens can be introduced in a human population.

Intermediate hosts can also serve as a "mixing vessel" for the emergence of new viral strains when such a host is infected by two or more viruses (Figure 3). In brief, a new (hybrid) viral strain from parental viruses can originate from recombination or reassortment. In recombination, gene fragments from parental viruses are recombined, resulting in a virus with a chimeric genomic molecule that contains regions of nucleotide sequence derived from each parental virus. In reassortment, two or more parental viruses exchange genome segments, also originating a hybrid virus (McDonald et al., 2016). For example, swine species can host influenza viruses from birds and humans, allowing genetic reassortment and the emergence of new viral strains (Shi et al., 2014).

The intensity and frequency of human interactions with livestock, companion animals, and wild species are very large. Such interactions create even more opportunities for the occurrence of spillover events. However, not all spillover events result in new human diseases or epidemics. The emergence of a new human disease and its dissemination in the population occurs only when biological, social, and environmental conditions are favorable for the replication/adaptation of the pathogen in the human host and its transmission among the new population. In general, if the pathogen shows low virulence or if its transmissibility is limited, the spillover will be of no medical importance. In other words, there will be no new human disease or the pathogen will not spread among the population. "Dead-end spillover" is an expression 


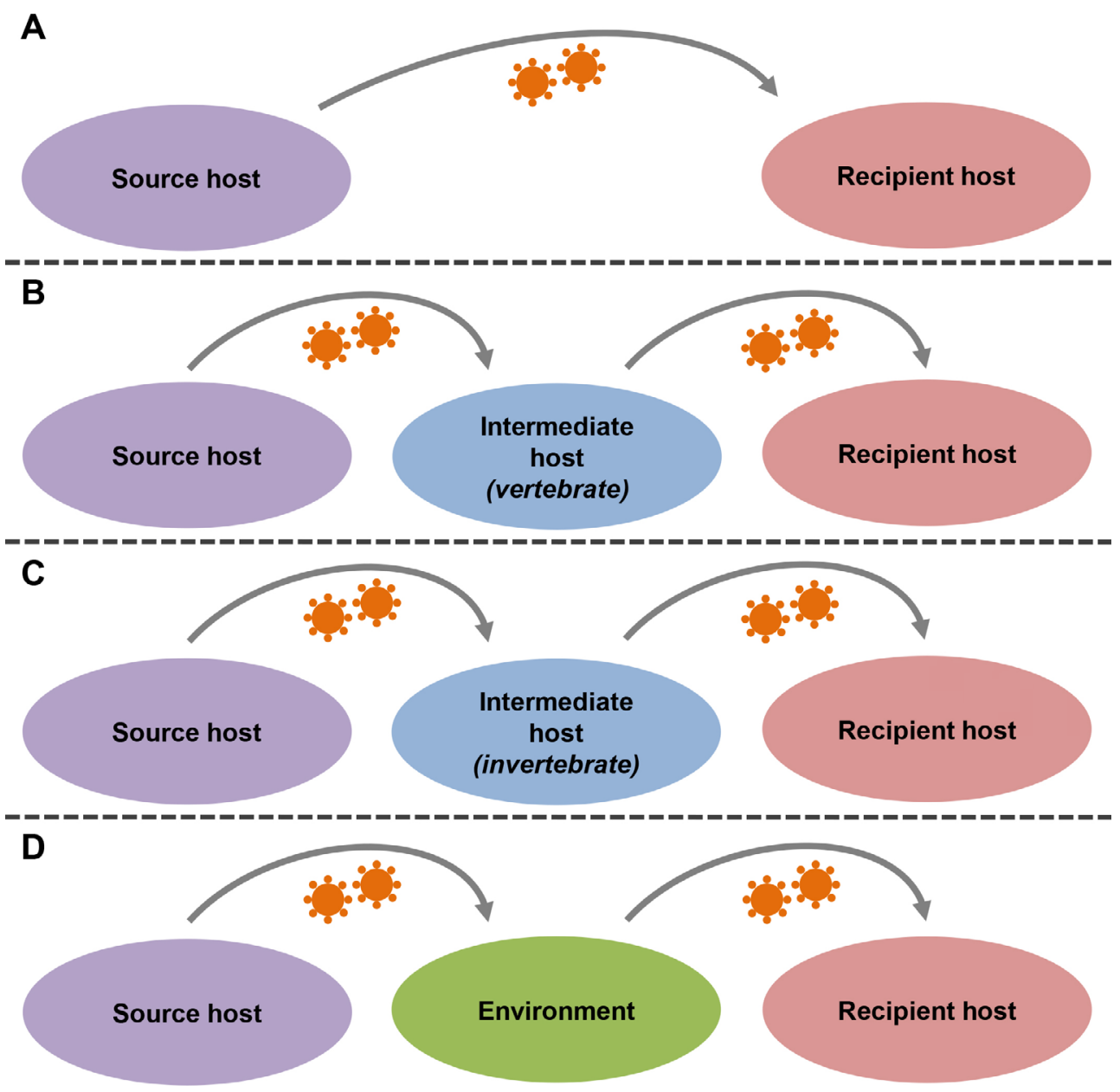

Figure 2 - Models of zoonotic spillover. Pathogens can overcome the barriers between species in different ways. A: the pathogen can be transmitted directly from the source host to the recipient host (e.g., a virus is transmitted from a bat to a human, via a bat bite). B: the pathogen can be transmitted from the source host to an intermediate vertebrate host and then be transmitted to the recipient host (e.g., a protozoan is transmitted from a wild species to a domestic dog, which then transmits the parasite to a human host). C: the pathogen can be transmitted from the source host to an intermediate invertebrate host and then be transmitted to the recipient host (e.g., an arbovirus is transmitted from a wild primate to a mosquito, which then transmits the virus to a human host). D: the pathogen can be transmitted from the source host to the environment and then be transmitted to the recipient host (e.g., a swine species releases an enterovirus into the environment through feces, which subsequently infects a human who has come into contact with the animal's feces present in the environment).

generally used to characterize the situation when a pathogen is transmitted to a human, but this event is not followed by spreading among the human population. Although spillover events that result in new human diseases are not common, when they do occur, the impacts can be very important, either by the appearance of a new human disease per se, or by the spread of the new disease on a large scale (Wolfe et al., 2005; Morse et al., 2012; Geoghegan et al., 2016; Plowright et al., 2017). Figure 4 shows schematically a dead-end spillover and a spillover followed by the spread of the pathogen among the population.

Finally, it is important to emphasize that the transmission of microorganisms between different species, without humanassociated disease, is common in nature. For example, it is currently known that inter-kingdom horizontal virus transfer is a frequent phenomenon and has broadly influenced the evolution of RNA viruses (Dolja and Koonin, 2018).

\section{Factors that influence zoonotic spillover}

\section{Interactions between species}

A basic condition for the occurrence of a spillover event is the interaction between different species. In this sense, the chances of new pathogens being introduced in the human population increase as the interactions between humans and other animal species are more intense and frequent. Therefore, as expected, geographic range overlap facilitates the transmission of pathogens between species (Albery et al., 2020).

The industrial meat production chain might put the human population away from the risks associated with contact with farm animals and their pathogens. On the other hand, the growing demand for meat production puts meat industry workers, veterinarians and farmers in close and growing 

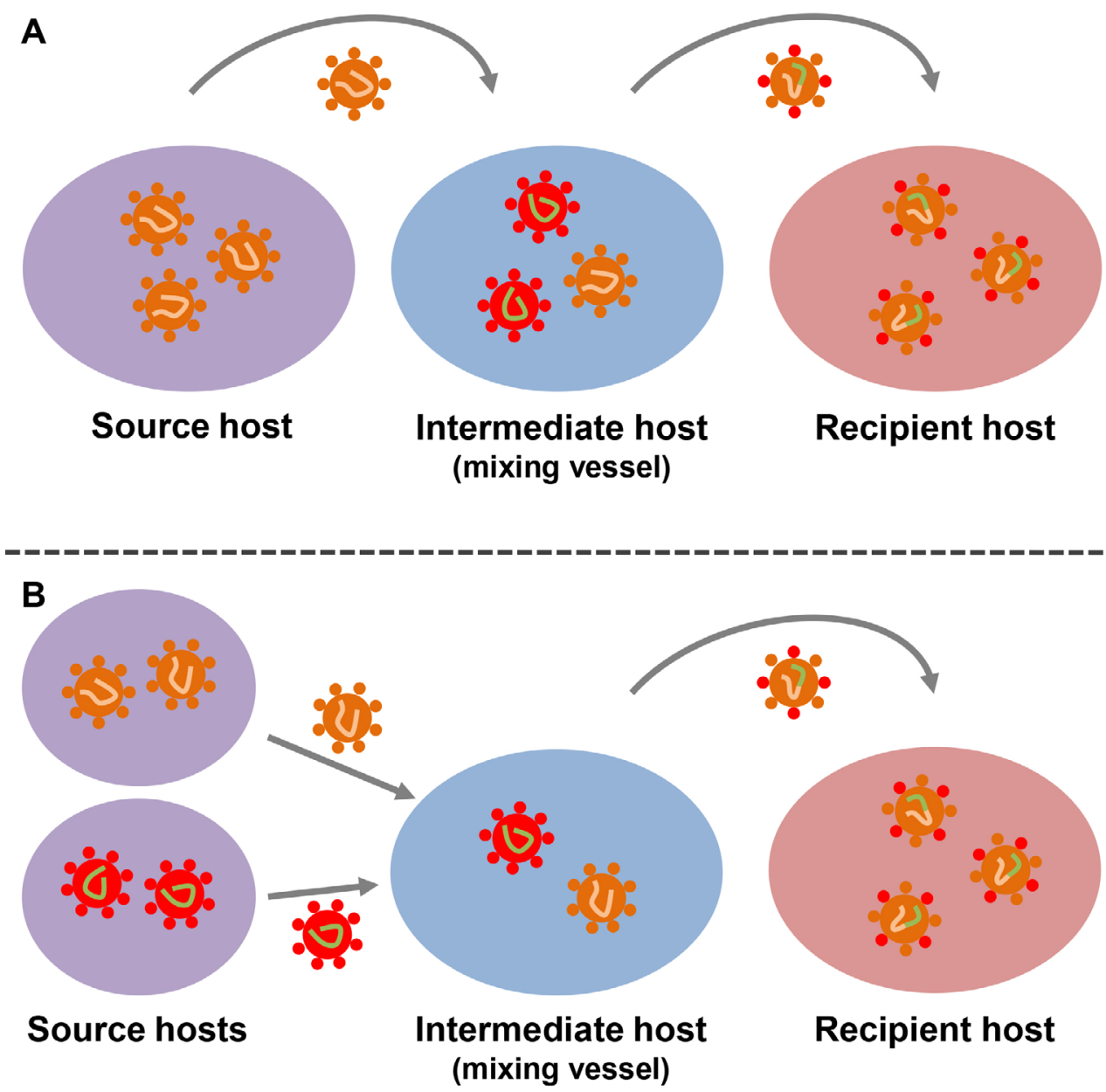

Figure 3 - Intermediate host as a "mixing vessel" for the emergence of new viral strains. When an intermediate vertebrate host is infected by different viral strains, recombination or reassortment can occur between viral species, generating new viral strains. The intermediate host can function as a mixing vessel of new viral trains in two ways. A: a viral strain from a source host exchanges genetic information with a viral strain originally present in the intermediate host, producing a new viral strain. B: the intermediate host is infected with viral strain from two (or more) source hosts, allowing the exchange of genetic information between the viral species, producing a new viral strain. Hypothetical viral recombination in an intermediate host is exemplified in this figure, but the same processes can be applied to viral reassortment.

contact with livestock animals, such as poultry, swine, and cattle. Adding to this, sometimes professionals of the meat industry do not have adequate working conditions to reduce the risks of infection by zoonotic pathogens or do not know sufficiently, or neglect, the health risks involved in their work activities (Cunha et al., 2012; Tebug et al., 2015; Hundal et al., 2016; Klous et al., 2016). Livestock animals are sources of different human pathogens, such as influenza virus strains, bacteria, and protozoa (Tomley and Shirley, 2009). Companion animals can also transmit zoonotic diseases/pathogens to humans, including parasites, bacterial and viral diseases, and fungal infections. Rabies is a classic example of viral zoonosis often transmitted from unvaccinated domestic animals to humans, especially in low and medium income countries (Chomel, 2014).

The interaction of humans with wild species plays a prominent role in the emergence of new human diseases since wild animals are natural reservoirs of many unknown pathogens. As previously mentioned, HIV emerged in the human population from the interaction with meat/blood of wild primates (Hahn et al., 2000; Sharp and Hahn, 2011). Also, Nipah, Ebola and Hendra are examples of pathogens that caused outbreaks in the human population from the interaction of humans with other animal species, which is frequently associated with changes in the behavior of wild species resulted from anthropogenic modifications of the natural environment (Fiel et al., 2001; Pigott et al., 2014; Saéz et al., 2015; Clayton, 2017). Sociocultural factors such as hunting, trade and consumption of meat from wild species (bushmeat) facilitate spillover events because these human actions put humans in close contact with fresh meat, offal and blood of animals that can host different pathogens (Hahn et al., 2000; Wolfe et al., 2005). As a general rule, the interaction between humans and animal species, in different ways, is a fundamental step for a spillover event. However, factors specific to pathogens, humans and animals will define whether the human contact with a new pathogen will or will not result in disease and, eventually, in an outbreak or epidemic. Therefore, to understand the aspects that determine zoonotic spillover events, it is necessary to consider the One Health 

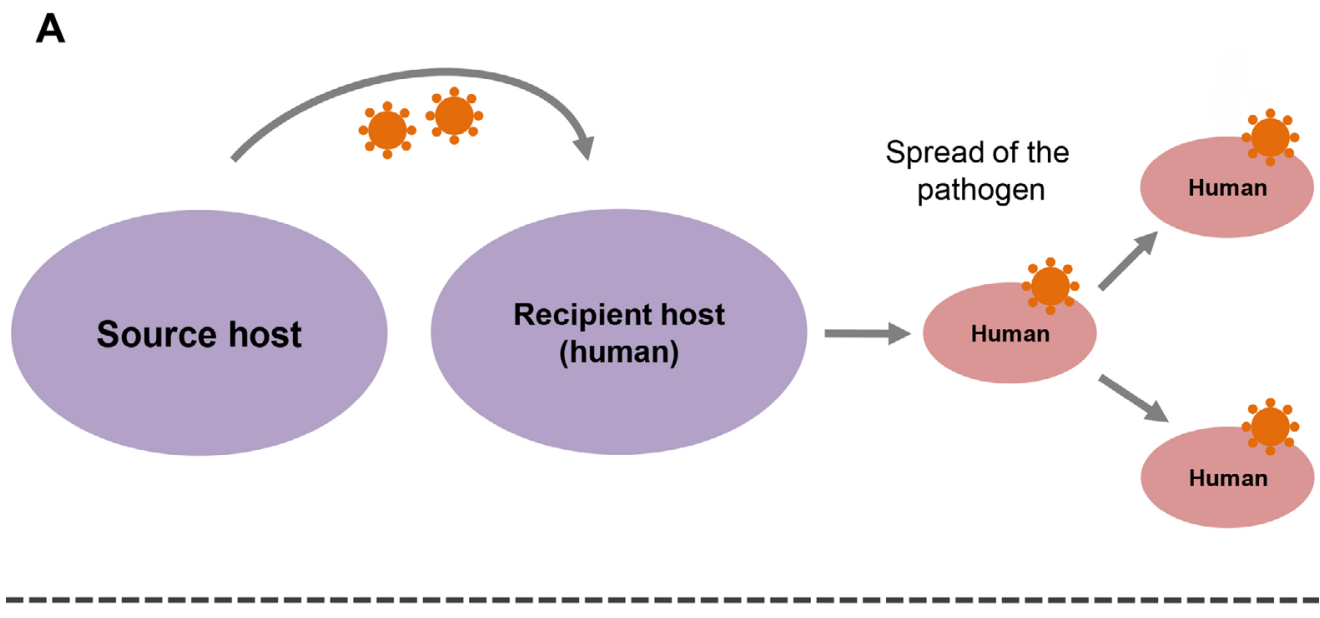

B

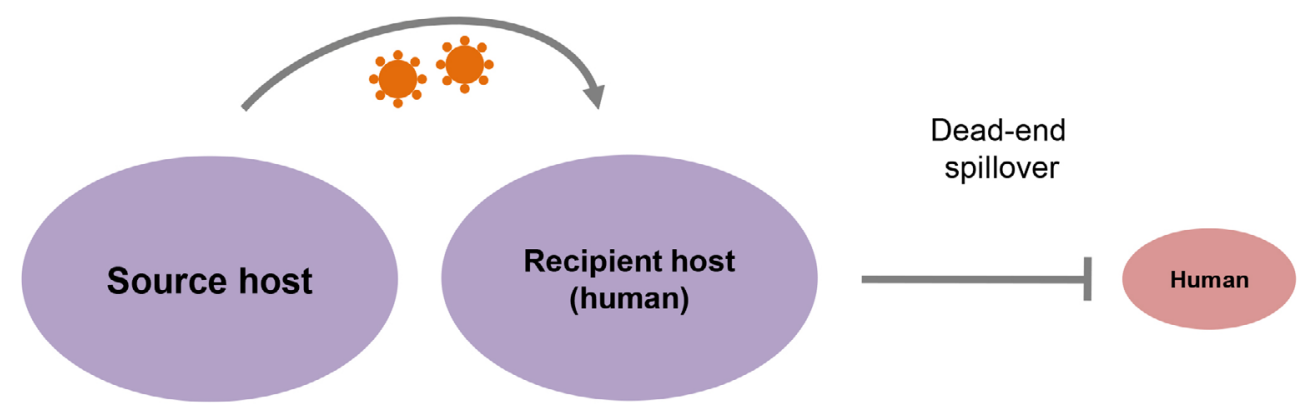

Figure 4 - Outcomes after a spillover event. A spillover event can have two basic outcomes. A: the pathogen that crossed the barriers between species can spread among the population (through human-to-human transmission or a highly competent vector). This outcome will occur if the social, biological, and environmental conditions are favorable for the adaptation of the pathogen in the human host and its transmission among the new population. B: the pathogen is transmitted to a human, but without spreading among the human population due to the absence of social, biological, or environmental conditions favorable to the adaptation of the pathogen to the human population or its dissemination. This condition is called dead-end spillover.

approach, integrating human, animal and environmental factors in the study, surveillance and prevention of emerging zoonotic diseases (Thompson, 2013; Bonilla-Aldana et al., 2020; Marty and Jones, 2020).

\section{Phylogenetic distance between host species}

The phylogenetic distance between source and recipient hosts is an important factor in spillover events. It is assumed that the chances of a pathogen being transmitted between phylogenetically similar species are greater compared to the chances of transmission between phylogenetically distant hosts (Davies and Pedersen, 2008; Han et al., 2016; Olival et al., 2017). For instance, the spillover of pathogens between two species of mammals (non-human primates to humans, for example) would be a more likely event than a spillover event involving a species of mammal and a reptile. However, this is not a stricter rule. The spillover of a particular pathogen between phylogenetically distant species may occur if there is interaction between these species and the pathogen finds basic conditions of infection and adaptation in the new host (Parrish et al., 2008; Walker et al., 2018; Albery et al., 2020).

Source and recipient hosts with high genetic similarity also show similarities regarding body physiology and cellular receptors (Walker et al., 2018). As a consequence, since similarity increases the chance of the virus interact with cells of the new host, high similarity of cellular receptors between host species can facilitate the spillover of viral pathogens (Bae and Son, 2011; Cho and Son, 2019; Wasik et al., 2019). Moreover, host genetic factors dictate the ability of a virus to replicate in a new host and, therefore, to establish productive infection and transmission in the new population (Warren and Sawyer, 2019).

Recently, Guth et al. (2019) evaluated how phylogenetic distance impacts the virulence and transmissibility of zoonotic viruses. In brief, the authors analyzed primarily a database containing 420 virus-mammal associations including 67 zoonotic viruses and 278 mammalian hosts, and found some patterns involving transmissibility and virulence. First, Guth 
et al. (2019) corroborate that the risk of spillover is higher among species with greater phylogenetic proximity. The authors also observed that reservoir animals phylogenetically close to humans generally host zoonotic pathogens of lower impact associated with morbidity and mortality (reduced virulence), but with greater transmissibility between humans. On the other hand, animals with a greater phylogenetic distance from humans are more likely to host highly virulent zoonoses (viruses with increased virulence), but with a limited capacity for human-to-human spread (reduced transmissibility) (Guth et al., 2019).

Comparing the mammalian orders Primates, Perissodactyla, Carnivora, Cetartiodactyla, Chiroptera, Eulipotyphla, Lagomorpha and Rodentia, bat-borne viruses (viruses from Chiroptera) were classified as the most virulent agents of mammalian zoonoses (Guth et al., 2019). However, bats can also host viruses with low or moderate virulence (e.g., coronaviruses) and, therefore, these particular bat-borne viruses can indeed spread widely among the human population in some situations, as observed in the SARS-CoV-2 pandemic.

\section{Characteristics of the pathogens}

Generalist pathogens, with the ability to infect a broad host range, are more able to jump the barrier between species than specialist pathogens (Johnson et al., 2015). Some characteristics of the pathogens facilitate the transmission between species. For example, viruses with an RNA genome have higher mutation rates and more frequent gene rearrangements. These characteristics increase the chances of adaptation to new host species (Nichol et al., 2000). Indeed, most zoonotic viruses have RNA genome (Johnson et al., 2015). Moreover, some authors found an association between viral replication in the cytoplasm and greater zoonotic potential (Pulliam and Dushof, 2009; Olival et al., 2017).

Different viral taxonomic groups have varied zoonotic potential (Olival et al., 2017; Washburne et al., 2018). For example, looking at mammalian viruses, the Alphavirus and Deltaretrovirus genera have a large proportion of zoonotic viral species. On the other hand, the families Papillomaviridae, Herpesviridae, Caliciviridae, Adenoviridae, and Astroviridae have few zoonotic representatives. This demonstrates that distinct taxons can be associated with varied risks of spillover. Based on zoonotic representatives and viral characteristics, the family Togaviridae has a high spillover potential. On the other hand, the family Herpesviridae shows low spillover potential (Washburne et al., 2018).

In the case of spillover involving indirect transmission, the resistance of the pathogen in the environment or feces/ secretions of animals will determine the success of the transmission between species. Non-enveloped viruses are more resistant outside the host, a feature that facilitates indirect transmission (Geoghegan et al., 2016; Walker et al., 2018).

After a spillover event, the ability of a viral species to be transmitted by direct contact (human-human transmission) facilitates its dissemination among the human population. The ability to cause long-term chronic infection, the presence of non-segmented genome, the absence of viral envelope, high host plasticity, and the infection of the respiratory tract are some characteristics that can facilitate the spread of viral species, favoring the emergence of an outbreak or epidemic (Johnson et al., 2015; Geoghegan et al., 2016; Walker et al., 2018; Guth et al., 2019). However, it is important to highlight that some viral characteristics, such as the capacity of humanhuman transmission and chronic infection, are most strongly associated with the ability of a pathogen to spread among the population after a spillover event, and do not necessarily facilitate spillover events per se, although some specific viral characteristics, such as the virus stability in the environment, may facilitate both processes (Geoghegan et al., 2016; Walker et al., 2018).

Finally, the extensive and often inappropriate use of antimicrobial drugs in the medical and veterinary field, especially antibiotics, acts in the selection of microorganisms resistant to different classes of such drugs (Woolhouse et al., 2015). For instance, data from Brazilian hospitals indicate that the rate of methicillin-resistant Staphylococcus aureus ranges from $30 \%$ to $60 \%$, and may be above $60 \%$ in some locations (Rossi, 2011). Microbial resistance is also a growing problem in livestock animals of Brazilian farms (Rabello et al., 2020). As a consequence, treatment options for multiresistant strains become increasingly scarce and create new opportunities for the circulation of resistance genes between humans, other animals and the environment (Woolhouse et al., 2015).

\section{Animal host-associated factors}

Animal species act as natural reservoirs for microbial species, eventually serving as "sources" of new human pathogens. Specifically, wild species are reported as the source of most zoonotic viral diseases (Johnson et al., 2015). For example, bats are classically known as natural reservoirs of various pathogens, especially viruses, which cause disease in humans (Calisher et al., 2006). The role of bats as reservoirs of multiple viruses is due to the capacity of the immune system of these animals to deal with a wide variety of pathogens. Although it was suggested that this particular immune function may be favored by the increased body temperature and metabolism observed in bats (O'Shea et al., 2014), the immune mechanisms that enable bats to deal with different viruses are still under investigation (Ahn et al., 2019).

The ecological habits of bats, which frequently share the environment with humans and domestic/livestock animals (Gomes et al., 2010; Esbérard et al., 2014; Russo and Ancillotto, 2015; Nunes et al., 2017), the abundance and high diversity of bat species in nature (Mickleburgh et al., 2002; Calisher et al., 2006), and the abundance of zoonotic pathogens found in such animals (Olival et al., 2017) are some factors that can facilitate the spillover of pathogens from bats to humans.

Bats have already been involved in the emergence of different human infectious diseases, such as Ebola, Nipah, Hendra, and SARS (Saéz et al., 2015; Wang and Anderson, 2019). Bats have received special attention in recent years among researchers investigating potential new human pathogens in wildlife. This focus on bats has likely overestimated their role in the emergence of infectious diseases. Recent data indicate that other animal groups can host as many, or even more, zoonotic pathogens as bats. Of note, there is little variation in proportion of zoonotic viruses found in 
different taxonomic orders (Mollentze and Streicker, 2020). Besides bats, other species may also play an important role in the emergence of new human infectious diseases but are being neglected, including wild rodents and livestock animals for meat production.

The production of meat and derived products cause direct impacts (livestock as source of human pathogens) and indirect effects (e.g., contributing to biodiversity loss and climate change) on the dynamics of infectious diseases (Rohr et al., 2019; Morand, 2020). Livestock animals can transmit pathogens to humans, contributing to the emergence of epidemics and pandemics. For example, different influenza strains, such as H1N1pdm09, were introduced into the human population after viral reassortment in swine reared for human consumption (Shi et al., 2014). According to Cleaveland et al. (2001), 77\% of pathogens from livestock animals can infect multiple hosts. Swine species can act as reservoirs of many other pathogens, including hepatitis E virus, Streptococcus suis, and Taenia solium (Da Silva et al., 2018; Chu et al., 2019). Livestock and domestic animals can also transmit pathogens to wild species (Mahapatra et al., 2015; Bevins et al., 2018). Conversely, wild animals can transfer pathogens to livestock (Musoke et al., 2015).

Along with livestock and wild species, domestic animals can act as source host of many human pathogens, including emerging viruses (Reperant et al., 2016). For example, catto-human transmission of the avian influenza A virus (H7N2) was recently reported (Lee et al., 2017; Poirot et al., 2019).

In addition to serving as natural reservoirs of pathogens, animals may have other roles in the transfer of pathogens between different species. Some animals can act as bridges/ intermediate hosts in spillover events. For example, dogs can easily transit between domestic environments and forest areas, potentially transferring pathogens from wild animals to humans. This phenomenon occurs especially in urban areas located close to forest landscapes (Ellwanger and Chies, 2019). Animal vectors can also act as intermediate hosts. In this sense, mosquitoes can carry arboviruses from wild primates to humans, being at the interface of the sylvatic and urban cycles of arboviral diseases such as Dengue and Yellow Fever (Chen and Vasilakis, 2011; Weaver, 2013; Possas et al., 2018).

\section{Environmental factors}

The loss of biodiversity is associated with the emergence and spread of infectious diseases. Conversely, forests and other natural landscapes with high abundance of animal species have a greater capacity to "maintain" pathogens in the wild environment, reducing the risk of zoonotic spillover from wildlife to humans (LoGiudice et al., 2003; Keesing et al., 2010; Civitello et al., 2015; Ostfeld, 2017; Gibb et al., 2020). In this sense, LoGiudice et al. (2003) showed that the preservation of vertebrate biodiversity was associated with reduced incidence of Lyme disease. An explanation for the pivotal role of biodiversity on health promotion is the "dilution effect". In brief, high diversity of host species decreases, or "dilutes", the prevalence of infection in high competent reservoir hosts, which reduces the risk of spillover events and human infection (Schmidt and Ostfeld, 2001; Johnson and Thieltges, 2010; Civitello et al., 2015; Khalil et al., 2016; Ostfeld, 2017). Also, biodiverse landscapes have many species that interfere with the transmission of pathogens through numerous mechanisms, reducing the risk of human infection (Johnson and Thieltges, 2010; Civitello et al., 2015).

Land-use changes reduce the richness and abundance of terrestrial species (Newbold et al., 2015) and are one of the main drivers of emerging infectious diseases, facilitating the emergence of vector-borne and zoonotic diseases (Loh et al., 2015; Gibb et al., 2020). In brief, extensive agriculture and the transformation of forest areas in pasture facilitate the emergence and spread of new human diseases since these processes favor the proliferation of generalist small species that host many pathogens (e.g., rodents), increase the load of pathogens in such species, and also contribute to climate change, which affects vector dynamics (e.g., expansion of areas infested by mosquitoes that transmit arboviruses). In sum, the risk of zoonotic diseases increases in places where natural landscapes are replaced by croplands, pastures or have been submitted to other human-related land changes (Keesing et al., 2010; Loh et al., 2015; Rohr et al., 2019; Wilke et al., 2019; Ellwanger et al., 2020; Gibb et al., 2020; Mendoza et al., 2020; Ostfeld and Keesing, 2020).

In Brazil, land-use changes and agricultural intensification are among the main drivers of the emergence of zoonotic diseases in humans, considering data from 1940 to 2005 (Keesing et al., 2010). Also, environmental degradation and loss of biodiversity promote the spread of animal vectors and pathogens to different areas, facilitating the transposition of pathogens between different species. In this sense, the construction of roads, human habitations and hydroelectric power plants in forest areas, in addition to other deforestationassociated activities, approximates humans to wild species and their pathogens, creating the basic conditions for the occurrence of zoonotic transfer (Ellwanger et al., 2020). In accordance, Ebola outbreaks in Africa are associated with forest fragmentation and deforestation (Rulli et al., 2017). Although the reasons for this association are not completely clear, anthropogenic changes in forest areas probably put humans in closer contact with Ebola reservoirs due to ecological and social factors linked to modifications in reservoir behavior and disturbances to wildlife, including hunting, bushmeat consumption, and landscape changes (Rulli et al., 2017). Moreover, land-use changes and environmental conditions that facilitate the proliferation of animal vectors and urban rodents can facilitate the introduction of pathogens in the human population and the spread of diseases (Himsworth et al., 2013; Cruvinel et al., 2020).

Several environment-related factors (e.g., abiotic conditions, parasite pressure, the presence of contaminants) affect the immune system of different species and populations, including humans, livestock and wild animals. Therefore, environment-related factors affect the immune system of source hosts, influencing the abundance and diversity of pathogens found in such animals, as well as the immune defenses of recipient hosts. As a consequence, the risks of spillover events will also be dependent on the effects of the environment on the immune system of source and recipient hosts. The immunological peculiarities of source species distributed across different geographic regions will also affect the risk of 
spillover events, which adds complexity to the understanding of disease ecology (Davis, 1998; Bowden, 2008; Bean et al., 2013; Kreitinger et al., 2016; Becker et al., 2020).

Finally, environmental factors such as microclimate and rain patterns modify the behavior of reservoir species and recipient hosts, as well as the viability of the pathogens in the environment. As a consequence, these modifications affect the occurrence of spillover events and the risk of transmission of pathogens from wildlife to humans (Martin et al., 2017, 2018; Schmidt et al., 2017; Cortes et al., 2018; Giles et al., 2018).

\section{Human host-associated factors}

Many factors that influence spillover events are modulated by human activity, including land-use change, interactions with different animal species, and the trade and consumption of meat from wild animals. In addition to these sociocultural factors, immunological and genetic factors also affect the human susceptibility to infections.

The characteristics of the immune responses (e.g., activity of Toll-like receptors and Th1/Th2 cell types) dictate the abundance and variety of pathogens found in the host, since the immune system modulates the susceptibility to infections and the adaptation of a particular pathogen to the host (Mukherjee et al., 2016; Ellwanger et al., 2018a). For instance, immunocompromised individuals are more susceptible to infection by opportunistic pathogens (Kovacs and Masur, 2000; Brown et al., 2012). Also, susceptibility/ resistance to infectious diseases is strongly modulated by host genetic factors (e.g., HLA alleles and chemokine genes), including polymorphisms in coding and non-coding regions (Cooke and Hill, 2001; Quintana-Murci et al., 2017; Ellwanger et al., 2018b). For example, the NLRP3 (rs10754558) gene polymorphism was associated with protection against HTLV1 infection in individuals from northeastern Brazil (Kamada et al., 2014). Recently, a study involving HIV-infected individuals showed that the $I L-4$ (-590C/T, rs2243250) gene polymorphism is associated with susceptibility to Pneumocystis jirovecii pneumonia (Wójtowicz et al., 2019). From a broader perspective, these data indicate that the immune status and genetic factors influence the susceptibility/resistance of humans to new infectious diseases from wildlife, thus affecting the chances of a new pathogen adapting to the human population (Matzaraki et al., 2017; Plowright et al., 2017; Ellwanger et al., 2018b).

Finally, it is important to highlight that humans can transmit pathogens to non-human hosts ("reverse zoonosis"), potentially introducing diseases in new animal populations (Nelson and Vincent, 2015). For instance, humans can transmit Mycobacterium tuberculosis to cattle (Mittal et al., 2014). Strains of the influenza virus are often transmitted from humans to swine (Nelson and Vincent, 2015). Also, a probable human-to-porcine transmission of rotavirus strains was recently reported in Brazil (Neves et al., 2020), and there is evidence of the transmission of SARS-CoV-2 from humans to dogs (Sit et al., 2020). Reverse zoonosis is a concern in terms of both public health and wildlife conservation (Olival et al., 2020).

\section{Zoonotic spillover and emerging infectious diseases: looking at Chinese and Brazilian contexts}

In late 2019, cases of an unknown infectious respiratory disease were detected in the city of Wuhan, Hubei province, central China. Early investigations pointed out that many individuals affected by the new disease had frequented a popular wet market in Wuhan, where various species of animals were sold for human consumption, as well as animal products used in traditional Chinese medicine. This information raised concerns of scientists and health officials, who realized that a new disease from wild species was emerging in the human population (Cohen and Normile, 2020; Cyranoski, 2020a, 2020b).

A few weeks after the first cases of infection were reported, the genomic material of the etiologic agent of this new disease was sequenced and characterized. The pathogen was identified as a Betacoronavirus, the SARS-CoV-2, an RNA virus that causes the disease now known as COVID-19 (Cohen and Normile, 2020; Liu, 2020; Wu et al., 2020). Currently, the COVID-19 pandemic is already the most important public health emergency of recent human history.

Some aspects of this pandemic have been compared to the 1918-1919 Spanish Flu, the "mother of all pandemics" (Taubenberger and Morens, 2006), due to the medical, economic, and social impacts that SARS-CoV-2 has unleashed on society. For example, Spanish Flu and COVID-19 show similar case-fatality rates $(\sim 3 \%)$ (Taubenberger and Morens, 2006; Lee, 2020). However, these data should still be taken with caution, since the COVID-19 pandemic is ongoing and the actual case-fatality rate can change. Interestingly, due to the current high number of commercial air travel, the COVID-19 pandemic spread around the world much faster than the Spanish Flu (Lee, 2020). Also, it is likely that the number of deaths from COVID-19 will be much lower than that recorded in the Spanish Flu due to the particular characteristics of SARSCoV-2 and the current global health systems. Spanish Flu affected approximately 500 million individuals worldwide, causing 50 million deaths (Taubenberger and Morens, 2006). About a year after the COVID-19 pandemic emerged, SARSCoV-2 infected more than 69 million individuals worldwide and caused approximately 1.6 million deaths (data collected on December 10, 2020). On the same date, China registered more than 93 thousand cases and Brazil was close to reaching 8 million cases (Dong et al., 2020; Johns Hopkins University, 2020). The number of SARS-CoV-2-infected individuals is probably much higher than the official reports because most cases of infection are mild or asymptomatic (Zhang and Holmes, 2020). Looking at human-related biological aspects, SARS-CoV-2 has spread easily around the world because the $A C E 2$ gene receptor (which encodes the protein used by the virus to penetrate cells) is highly conserved in different human populations (Fam et al., 2020).

Recent genomic analyzes show that SARS-CoV-2 is similar to coronaviruses found in bats: $96 \%$ similar to BatCoVRaTG13 strain (Zhou et al., 2020a) and 93\% similar to RmYN02 strain at level of complete virus genome (Zhou et al., 2020b). However, these bat viral strains are sufficiently 
different from SARS-CoV-2 to indicate the existence of an intermediate host. Bats are source hosts of the MERS-CoV and SARS-CoV, other coronaviruses responsible for human epidemics in past recent years (de Wit et al., 2016). Taking together, these findings and others (Latinne et al., 2020) suggest that bats are also involved in the emergence of the COVID-19 pandemic, as a host source, and that another animal could have acted as an intermediate host.

Human SARS-CoV pandemic occurred between 2002 and 2003, causing 774 deaths in 27 countries. MERS-CoV emerged in the human population in 2012, causing more than 600 deaths and also affecting 27 countries (de Wit et al., 2016). In SARS-CoV and MERS-CoV outbreaks, palm civets (Paguma larvata) and dromedary camels (Camelus dromedarius), respectively, acted as intermediate hosts during zoonotic spillover. In other words, these animals facilitated the transmission of SARS-CoV/MERS-CoV precursor coronaviruses from bats to humans (Guan et al., 2003; Chu et al., 2014; de Wit et al., 2016; Jin et al., 2020; RodriguezMorales et al., 2020). In the case of SARS-CoV, it is probable that, besides palm civets, other species acted as intermediate hosts (de Wit et al., 2016), including raccoon dogs (Nyctereutes procyonoides) (Guan et al., 2003; Mallapaty, 2020).

Much debate exists about which species would have acted as an intermediate host in the emergence of SARS-CoV-2 in the human population. Genomic analysis indicates that pangolins (Manis javanica) may have played this role, once these animals host coronaviruses very similar, genetically, to SARS-CoV-2 (Lam et al., 2020; Zhang et al., 2020). Of note, these animals are used in traditional medicine and are appreciated in the Chinese gastronomic culture, moving a large trade of these animals and raising great concerns in terms of conservation, especially because pangolins have a low reproductive rate (one offspring per year) (Liu and Weng, 2014; Zhou et al., 2014). On the other hand, some data support that the viral strain that originated SARS-CoV-2 may have been circulating in bat populations for many years (maybe since the 1940s or before that) and subsequently been transmitted to humans without necessarily the participation of an intermediary host (Boni et al., 2020). Indeed, although the initial genomic analysis indicated that pangolins may have been intermediate hosts in the SARS-CoV-2 spillover, other animals can also host coronavirus strains as similar to SARS-CoV-2. These other animals may just have not been evaluated yet. In other words, in addition to the probable involvement of bats as natural reservoirs of SARS-CoV-2-related coronaviruses, the data already accumulated do not allow us to state which animal species were indeed involved in the introduction of SARS-CoV-2 in the human population (Zhang and Holmes, 2020). The World Health Organization intends to investigate in the field the conditions that contributed to the emergence of SARS-CoV-2 in the human population. The investigation will cover the city where the fist cases of COVID-19 were detected, Wuhan, as well as other Chinese cities and countries (Mallapaty, 2020).

It is also not possible to state the particular steps that SARS-CoV-2 took until the introduction and spread in the human population. The introduction of a pathogen from a wild animal to the human population can be a gradual (multistep) process, through several spillover events, as well as involving multiple intermediate hosts (Wolfe et al., 2007; Bean et al., 2013; de Wit et al., 2016). Also, SARS-CoV-2 may have surged from recombination of coronaviruses of bats and pangolins. In this case, pangolins would have acted as an intermediate reservoir and a "mixing vessel" for the emergence of SARSCoV-2 (Li et al., 2020; Xiao et al., 2020). However, these assumptions remain under investigation and much debate (Boni et al., 2020), and the pieces of this puzzle continue to be assembled.

On the other hand, the available data is already sufficient to affirm that SARS-CoV-2 is a virus resulting from natural processes involving the interaction of humans with other species (Andersen et al., 2020). In China, wet markets are part of the national culture (Zhong et al., 2020), demanding large volumes of wild and live animals to supply restaurants and family consumption. It was estimated that 2 to 30 tons of live wild animals are transported into China daily (Yang et al., 2000; Wang et al., 2020). Inspection failures associated with poor sanitary conditions in wet markets create ideal conditions for spillover events in such places. This is the likely scenario in which the COVID-19 emergence occurred in the human population (Zhang and Holmes, 2020). However, the trade and consumption of wild animals and derived products are not exclusive to China but are present in several countries, including Brazil. Hunting and commercialization of meat from wild animals are intense and poorly inspected activities in Brazil, where several wild species are used for food and medicinal purposes (Alves et al., 2012; Sanches et al., 2012; Fonseca and Pezzuti, 2013; van Vliet et al., 2014; Chagas et al., 2015; Torres et al., 2016; Souto et al., 2018; El Bizri et al., 2020). However, there are many particularities in the demand for wild animals in Brazil and China.

Few data are available on the volume of wild meat commercialized in Brazil. In the Amazonian trifrontier of Brazil, Colombia and Peru, more than 470 tons of meat from wild animals is commercialized per year, as estimated by van Vliet et al. (2014). However, it is likely that this volume is even greater because such trade is illegal in such Amazonia countries and, therefore, very difficult to measure (van Vliet et al., 2014). An older study estimated that up to 89,224 tons of wild meat is consumed each year in the rural Brazilian Amazon (Peres, 2000). Of note, van Vliet et al. (2014) also estimated the commercialization of wild meat at $3.2 \mathrm{~kg} /$ habitant/year for the studied region (Brazil-Colombia-Peru trifrontier). A recent study estimated that 10,691 tons of wild meat are consumed annually in 62 cities of central Amazon. This amount of wild meat represents $6.49 \mathrm{~kg} / \mathrm{habitant} / \mathrm{year}$ (El Bizri et al., 2020).

Brazil is one of the world's largest producers of cattle meat (Neto, 2018). The availability of cattle meat in Brazil certainly reduces the consumption of bushmeat since it creates greater food security concerning the availability of this type of protein, at least at the national level. On the other hand, a study in the Brazil-Colombia-Peru trifrontier identified the average price of fresh bushmeat in the market places as USD\$ $5.32 / \mathrm{kg}$ (van Vliet et al. 2014). Since the price of bushmeat is comparable to the price of fresh beef (USD $\$ 6.2 / \mathrm{kg}$ ), this can serve as a stimulus for bushmeat consumption where 
this type of meat is available and part of the local culture. Another study performed in the central Brazilian Amazon estimated the price of one $\mathrm{kg}$ of wild mammal or bird for fresh meat at $\sim$ USD $\$ 2.00$ (and even less for dried meat) (Chaves et al., 2019), indicating that in some places of Brazil the consumption of meat from wild animals can indeed be financially advantageous.

As a consequence of the scenario mentioned above, the possibility of the emergence of new human infectious diseases in Brazilian territory exists and is generally neglected. However, it is necessary to draw the parallel between China and Brazil with criticism. The trade and consumption of meat from wild animals and derived products is part of Chinese culture and occurs in a huge scale. In Brazil, this is an illegal practice and is limited to some specific regions and populations, on a small scale compared to China. Besides, Brazil has a limited sales volume of wild meat (usually associated with illegal trade) compared to the widespread Chinese wet markets.

Previously the SARS-CoV-2 emergence, many researchers had warned that a new epidemic caused by a coronavirus could occur, causing an important impact on human society. They highlighted the need to improve surveillance and enhance the development of antiviral drugs and vaccines focused on coronaviruses (de Wit et al., 2016; Devi, 2017; Ng and Tan, 2017; Rabaan, 2017). In 2018 we call attention to the need to intensify the surveillance of zoonotic diseases and spillover events in the Brazilian territory (Ellwanger and Chies, 2018). These alerts must be translated into a more robust inspection of illegal hunting activities and commercialization of meat from wild animals in Brazil, associated with the intensification of epidemiological surveillance focusing on human-animal interfaces (Ellwanger et al., 2019). For example, many spillover events and limited outbreaks involving the Ebola virus in Africa are not detected by health systems or international health authorities (Glennon et al., 2019). Similarly, in Brazil, cases of several infectious diseases remain underreported due to the lack of compulsory notification of some diseases, misdiagnosis, and underdiagnosis (Dias et al., 2011; Oliveira et al., 2013; Brito and Teixeira, 2017; Rodrigues, 2017; Shikanai-Yasuda et al., 2017; Almeida et al., 2019). Hospital-based surveillance of zoonotic exposures can be very useful for early detection of the emergence of infectious diseases, in addition to providing more detailed information on spillover events (Das et al., 2019). These lessons should be taken very seriously in Brazil once the country is a hotspot for the emergence of new infectious diseases due to its rich diversity of animal species that host many zoonotic diseases and potential new human pathogens (Hotez, 2014; Han et al., 2016; Olival et al., 2017; Ellwanger and Chies, 2018). This is of particular concern in Brazil because in the country there is a growing anthropogenic interference in natural landscapes, such as the Amazon rainforest (Ellwanger $e t$ al., 2020). Brazil is also considered a hotspot for the emergence of zoonotic diseases because it concentrates different activities associated with land-use changes (e.g., agricultural practices) in the Amazon region (Ellwanger et al., 2020). As previously mentioned, land-use changes are among the main drivers of emerging infectious diseases (Keesing et al., 2010; Loh et al., 2015; Gibb et al., 2020).
In addition to the environmental problems observed in the Amazon region, Brazil harbors other highly biodiverse biomes. The Atlantic Forest, a huge biodiversity hotspot, has been degraded since the beginning of the European colonization in the $1500 \mathrm{~s}$, resulting in intense forest fragmentation and loss of habitats and diversity of plant and animal species (Ribeiro et al., 2011; Maioli et al., 2020). To the best of our knowledge, there are no estimates of the number of new zoonotic diseases that have emerged in the human population as a result of the degradation of this biome. However, some examples can be mentioned. In the 1970s, Brazil faced an important epidemic of human encephalitis caused by the emergence of the mosquitoborne Rocio virus in Vale do Ribeira and Baixada Santista, both regions of Atlantic Forest in the state of São Paulo (Lopes et al., 1978; Iversoon, 1980). More recently, Brasil et al. (2017) reported an outbreak of Plasmodium simiumassociated human malaria in the Atlantic Forest of Rio de Janeiro state. Plasmodium simium is traditionally considered a monkey-specific malaria parasite, and such data demonstrate the zoonotic transmission of the parasite in the region of the Atlantic Forest (Brasil et al., 2017). Finally, the 2016-2018 yellow fever outbreak affected wild primates and humans in Atlantic Forest regions of southeastern Brazil, which had remained free of yellow fever outbreaks for more than 80 years (Abreu et al., 2019).

Several other pathogens circulate in mosquito vectors (Barrio-Nuevo et al., 2020; Ximenes et al., 2020), bats (de Araujo et al., 2012; Góes et al., 2016; Gonçalves-Oliveira et al., 2020), wild rodents (Rozental et al., 2017; Vieira et al., 2019), non-human primates (Costa et al., 2014; Catenacci et al., 2018) and dogs (Curi et al., 2014; Sevá et al., 2018) found in portions of the Atlantic Forest and adjacent areas in different regions of Brazil. The interaction of animals with human populations that live in close contact with the Atlantic Forest can cause isolated cases of zoonotic infections in humans, maintain the endemicity cycles of diseases such as Leptospirosis and Leishmaniasis (Curi et al., 2014; Vieira et al., 2019), as well as create the ideal conditions for the emergence of new human infectious diseases in Brazil.

The urbanization process that occurs in areas previously occupied by forests favors the proliferation of vectors of different diseases. Currently, Brazil has a series of endemic arboviruses circulating in the Atlantic Forest region, such as Dengue, Zika and Chikungunya. The ecological connection between urban and forest environments, in association with the occurrence of different species of mosquitoes of medical importance in Atlantic Forest areas (Aedes albopictus, Aedes serratus, Aedes scapularis, Psorophora ferox, Haemagogus leucocelaenus, among many others) (Cardoso et al., 2011; Laporta et al., 2012; Alencar et al., 2016a,b), gives support for the circulation of different arboviruses between sylvatic and urban areas (Weaver, 2013; Figueiredo, 2019). Based on this scenario, it is likely that vector-mediated spillover (and spillback) events are the main problem in Brazil in terms of the risks of emergence of infectious diseases, unlike in China, where the greatest risks may be related to the bushmeat trade. However, this is an interpretation that needs to be further investigated. 
Epidemiological surveillance, early case identification and blocking measures are essential to adequately respond to the emergence of a new disease. It is important to note that China identified very rapidly the virus responsible for the COVID-19 pandemic, having sequenced the pathogen's genome in weeks after its emergence (Cohen and Normile, 2020; Liu, 2020). In situations of epidemics and pandemics, rapid responses are essential for understanding and controlling the disease. In Brazil, the SARS-CoV-2 genomes were also rapidly sequenced after the first two infection cases were detected in the country (de Jesus et al., 2020), which was essential to understand the dynamics of the pandemic in Brazil in an agile way. These good examples reinforce the importance of Brazilian scientists and health officials to strengthen the national structure of genome-based surveillance of emerging pathogens, as exemplified by studies addressing Chikungunya (Nunes et al., 2015), Zika (Faria et al., 2017), Yellow Fever (Hill et al., 2020) and SARS-CoV-2 (Candido et al., 2020) in the country. A surveillance strategy using next-generation technologies will be very useful to contain diseases that may emerge in the national territory, potentially affecting other countries, or that will eventually arrive in Brazil from other places (Ellwanger et al., 2017).

There are many problems in the Brazilian health system that need to be addressed, such as the national capacity for risk communication, health emergency response, laboratory capacity, environmental sanitation (Vicente, 2020). Finally, strengthening the Brazilian Unified Health System (Sistema Único de Saúde - SUS) is essential for future public health emergencies to be properly managed and contained in Brazil. Similar to the essential role played by SUS in controlling past public health emergencies, such as the Zika virus epidemic, the SUS is proving essential for the treatment of most COVID-19 patients (Ventura et al., 2020). The lack of engagement of a portion of government officials and population in taking effective measures to contain the spread of SARS-CoV-2 (e.g., wearing masks, social distance) is very worrying during the COVID-19 pandemic in Brazil and indicates that these aspects need be broadly improved so that the country could more effectively face future public health emergencies involving infectious diseases.

\section{Preventing spillover events}

Considering the factors that increase or decrease the risks of transfer of pathogens between species, together with the lessons learned from past outbreaks, epidemics, and pandemics, it is possible to list some actions to prevent spillover events based on the One Health perspective (Ellwanger and Chies, 2018; Ellwanger et al., 2020). Of note, many of these actions are also useful for the control of diseases already observed in human populations, such as vector-borne infections. Put in simple, the actions are: Improve sanitary control of livestock; Increase surveillance of pathogens at human-animal interfaces; Control hunting and trade of wild animals; Reduce deforestation and biodiversity loss; Improve the infrastructure of basic/environmental sanitation; Avoid the construction of human housing in forest areas; Control vectors and free-ranging animals; Increase investments in human training and laboratories focused on the identification of new pathogens and emerging diseases as well as the development of vaccines; Identify biological and social factors of susceptibility to infections; Create financial funds to finance the mitigation of the emergence of infectious disease outbreaks, shortly after spillover events; Regulate biosafety protocols for professional working with wildlife and livestock.

Based on the history of health crises, it is known that funds and health actions focused on outbreaks and epidemics tend to disappear after the end of such public health emergencies (Ventura et al., 2020). Therefore, it is necessary that actions focused on prevention of spillover events were applied constantly and systematically, preventing the emergence of new epidemics realistically. Finally, it is fundamental that the prevention and mitigation of public health emergencies took into account the social, political, and economic aspects of each population (Ventura et al., 2020).

\section{Conclusion}

Understanding the factors involved in zoonotic spillover events is essential to the development of better actions to control and prevent the emergence of new human diseases. Stimulating the study of the transmission of pathogens between species is very important, especially in Brazil, where few research groups are dedicated to this topic.

Importantly, no species should be eliminated or stigmatized due to the potential risks posed to humans. Each species has an ecological role in nature that must be respected. For example, although bats host a variety of pathogens, these animals provide key ecosystem services, such as pollination, pest control, seed dispersal, and are involved in several other ecological aspects (Mickleburgh et al., 2002; Olival, 2016; Pereira et al., 2020). The popular prejudice against bats is very worrying because many species of bats are at risk of extinction (Mickleburgh et al., 2002).

Although bats and other animal species are frequent "sources" of new human diseases, they are not the cause of these diseases. Human activities are the main facilitators of the transfer of pathogens from non-human animals to humans. Therefore, measures to prevent emerging diseases must be focused on human activities and the way humans interact with other species.

Spillover events and the emergence of new infectious diseases are connected. New pandemics such as COVID-19 will certainly occur in the next years, to a lesser or greater extent. Although these public health emergencies are recurrent in human history and cannot be avoided completely, it is possible to minimize the risk of occurrence of such phenomena. The intensity of each pandemic will also be a reflection of the health system. Researchers and health authorities must work together with the society to identify the main risk factors for spillover events in each region or country, applying actions to prevent them and strengthen the actions to rapidly contain diseases emergence after a spillover event.

Finally, spillover and emerging infectious diseases are highly connected with the way humans interact with animal species and the environment. This connection increases society's responsibility for the preservation of Brazilian biodiversity, once it is now very evident that nature preservation is also a public health need. 


\section{Acknowledgements}

JHE receives a postdoctoral fellowship from Coordenação de Aperfeiçoamento de Pessoal de Nivel Superior (Programa Nacional de Pós-Doutorado-PNPD/CAPES, Brazil). JABC receives a research fellowship from Conselho Nacional de Desenvolvimento Científico e Tecnológico (CNPq, Brazil) and has a research project funded by CAPES (Brazil).

\section{Conflict of Interest}

No conflicts of interest to declare.

\section{Author Contributions}

JHE wrote the initial version of the manuscript. JABC revised and edited the text. Both authors approved the final version of the manuscript.

\section{References}

Abreu FVS, Ribeiro IP, Ferreira-de-Brito A, Santos AAC, Miranda RM, Bonelly IS, Neves MSAS, Bersot MI, Santos TP, Gomes MQ et al. (2019) Haemagogus leucocelaenus and Haemagogus janthinomys are the primary vectors in the major yellow fever outbreak in Brazil, 2016-2018. Emerg Microbes Infect 8:218-231.

Aguirre AA, Catherina R, Frye H and Shelley L (2020) Illicit wildlife trade, wet markets, and COVID-19: Preventing future pandemics. World Med Health Policy 12:256-265.

Ahn M, Anderson DE, Zhang Q, Tan CW, Lim BL, Luko K, Wen M, Chia WN, Mani S, Wang LC et al. (2019) Dampened NLRP3mediated inflammation in bats and implications for a special viral reservoir host. Nat Microbiol 4:789-799.

Albery GF, Eskew EA, Ross N and Olival KJ (2020) Predicting the global mammalian viral sharing network using phylogeography. Nat Commun 11:2260.

Alencar J, de Mello CF, Serra-Freire NM, Guimarães AE, Gil-Santana HR and Gleiser RM (2016a) Biodiversity and temporal distribution of immature Culicidae in the Atlantic Forest, Rio de Janeiro State, Brazil. PLoS One 11:e0159240.

Alencar J, Mello CF, Barbosa LS, Gil-Santana HR, Maia DA, Marcondes CB and Silva JS (2016b) Diversity of yellow fever mosquito vectors in the Atlantic Forest of Rio de Janeiro, Brazil. Rev Soc Bras Med Trop 49:351-356.

Almeida MA, Almeida-Silva F, Guimarães AJ, Almeida-Paes R and Zancopé-Oliveira RM (2019) The occurrence of histoplasmosis in Brazil: A systematic review. Int J Infect Dis 86:147-156.

Alves RRN, Vieira KS, Santana GG, Vieira WLS, Almeida WO, Souto WMS, Montenegro PFGR and Pezzuti JCB (2012) A review on human attitudes towards reptiles in Brazil. Environ Monit Assess 184:6877-6901.

Andersen KG, Rambaut A, Lipkin WI, Holmes EC and Garry RF (2020) The proximal origin of SARS-CoV-2. Nat Med 26: 450-452.

Bae SE and Son HS (2011) Classification of viral zoonosis through receptor pattern analysis. BMC Bioinformatics 12:96.

Barrio-Nuevo KM, Cunha MS, Luchs A, Fernandes A, Rocco IM, Mucci LF, de Souza RP, Medeiros-Sousa AR, Ceretti-Junior W and Marrelli MT (2020) Detection of Zika and dengue viruses in wild-caught mosquitoes collected during field surveillance in an environmental protection area in São Paulo, Brazil. PLoS One 15:e0227239.

Bean AGD, Baker ML, Stewart CR, Cowled C, Deffrasnes C, Wang LF and Lowenthal JW (2013) Studying immunity to zoonotic diseases in the natural host - keeping it real. Nat Rev Immunol $13: 851-861$.
Becker DJ, Albery GF, Kessler MK, Lunn TJ, Falvo CA, Czirják GA, Martin LB and Plowright RK (2020) Macroimmunology: The drivers and consequences of spatial patterns in wildlife immune defence. J Anim Ecol 89:972-995.

Becker DJ, Washburne AD, Faust CL, Pulliam JRC, Mordecai EA, Lloyd-Smith JO and Plowright RK (2019) Dynamic and integrative approaches to understanding pathogen spillover. Philos Trans R Soc Lond B Biol Sci 374:20190014.

Bevins SN, Lutman M, Pedersen K, Barrett N, Gidlewski T, Deliberto TJ and Franklin AB (2018) Spillover of swine coronaviruses, United States. Emerg Infect Dis 24:1390-1392.

Boni MF, Lemey P, Jiang X, Lam TTY, Perry BW, Castoe TA, Rambaut A and Robertson DL (2020) Evolutionary origins of the SARS-CoV-2 sarbecovirus lineage responsible for the COVID-19 pandemic. Nat Microbiol 5:1408-1417.

Bonilla-Aldana DK, Holguin-Rivera Y, Perez-Vargas S, TrejosMendoza AE, Balbin-Ramon GJ, Dhama K, Barato P, LujanVega C and Rodriguez-Morales AJ (2020) Importance of the One Health approach to study the SARS-CoV-2 in Latin America. One Health 10:100147.

Borremans B, Faust C, Manlove KR, Sokolow SH and Lloyd-Smith JO (2019) Cross-species pathogen spillover across ecosystem boundaries: mechanisms and theory. Philos Trans R Soc Lond B Biol Sci 374:20180344.

Bowden TJ (2008) Modulation of the immune system of fish by their environment. Fish Shellfish Immunol 25:373-383.

Brasil P, Zalis MG, de Pina-Costa A, Siqueira AM, Júnior CB, Silva S, Areas ALL, Pelajo-Machado M, de Alvarenga DAM, da Silva Santelli ACF et al. (2017) Outbreak of human malaria caused by Plasmodium simium in the Atlantic Forest in Rio de Janeiro: a molecular epidemiological investigation. Lancet Glob Health 5:e1038-e1046.

Brito CAA and Teixeira MG (2017) Increased number of deaths during a chikungunya epidemic in Pernambuco, Brazil. Mem Inst Oswaldo Cruz 112:650-651.

Brown C (2004) Emerging zoonoses and pathogens of public health significance - an overview. Rev Sci Tech 23:435-442.

Brown SP, Cornforth DM and Mideo N (2012) Evolution of virulence in opportunistic pathogens: generalism, plasticity, and control. Trends Microbiol 20:336-342.

Calisher CH, Childs JE, Field HE, Holmes KV and Schountz T (2006) Bats: important reservoir hosts of emerging viruses. Clin Microbiol Rev 19:531-345.

Candido DS, Claro IM, de Jesus JG, Souza WM, Moreira FRR, Dellicour S, Mellan TA, du Plessis L, Pereira RHM, Sales FCS et al. (2020) Evolution and epidemic spread of SARS-CoV-2 in Brazil. Science 369:1255-1260.

Cardoso JC, de Paula MB, Fernandes A, dos Santos E, de Almeida MAB, da Fonseca DF and Sallum MAM (2011) Ecological aspects of mosquitoes (Diptera: Culicidae) in an Atlantic forest area on the north coast of Rio Grande do Sul State, Brazil. J Vector Ecol 36:175-186

Catenacci LS, Ferreira M, Martins LC, De Vleeschouwer KM, Cassano CR, Oliveira LC, Canale G, Deem SL, Tello JS, Parker P et al. (2018) Surveillance of arboviruses in primates and sloths in the Atlantic Forest, Bahia, Brazil. Ecohealth 15:777-791.

Chagas ATA, da Costa MA, Martins APV, Resende LC and Kalapothakis E (2015) Illegal hunting and fishing in Brazil: a study based on data provided by environmental military police. Nat Conserv 13:183-189.

Chaves WA, Monroe MC and Sieving KE (2019) Wild meat trade and consumption in the Central Amazon, Brazil. Hum Ecol 47:733-746.

Chen R and Vasilakis N (2011) Dengue - Quo tu et quo vadis? Viruses 3:1562-1608. 
Cho M and Son HS (2019) Prediction of cross-species infection propensities of viruses with receptor similarity. Infect Genet Evol 73:71-80.

Chomel BB (2014) Emerging and re-emerging zoonoses of dogs and cats. Animals (Basel) 4:434-445.

Chu DKW, Poon LLM, Gomaa MM, Shehata MM, Perera RAPM, Abu Zeid D, El Rifay AS, Siu LY, Guan Y, Webby RJ et al. (2014) MERS coronaviruses in dromedary camels, Egypt. Emerg Infect Dis 20:1049-1053.

Chu DT, Ngoc TU, Chu-Dinh T, Ngoc VTN, Van Nhon B, Pham VH, Nghia LL, Anh LQ, Van Pham TH and Truong ND (2019) The possible zoonotic diseases transferring from pig to human in Vietnam. Eur J Clin Microbiol Infect Dis 38:1003-1014.

Clayton BA (2017) Nipah virus: transmission of a zoonotic paramyxovirus. Curr Opin Virol 22:97-104.

Cleaveland S, Laurenson MK and Taylor LH (2001) Diseases of humans and their domestic mammals: pathogen characteristics, host range and the risk of emergence. Philos Trans R Soc Lond B Biol Sci 356:991-999.

Cohen J and Normile D (2020) New SARS-like virus in China triggers alarm. Science 367:234-235.

Cooke GS and Hill AVS (2001) Genetics of susceptibility to human infectious disease. Nat Rev Genet 2:967-977.

Cortes MC, Cauchemez S, Lefrancq N, Luby SP, Jahangir Hossain M, Sazzad HMS, Rahman M, Daszak P, Salje H and Gurley ES (2018) Characterization of the spatial and temporal distribution of Nipah virus spillover events in Bangladesh, 2007-2013. J Infect Dis 217:1390-1394.

Costa DC, da Cunha VP, de Assis GMP, de Souza Junior JC, Hirano ZMB, de Arruda ME, Kano FS, Carvalho LH and de Brito CFA (2014) Plasmodium simium/Plasmodium vivax infections in southern brown howler monkeys from the Atlantic Forest. Mem Inst Oswaldo Cruz 109:641-653.

Civitello DJ, Cohen J, Fatima H, Halstead NT, Liriano J, McMahon TA, Ortega CN, Sauer EL, Sehgal T, Young S et al. (2015) Biodiversity inhibits parasites: Broad evidence for the dilution effect. Proc Natl Acad Sci U S A 112:8667-8671.

Cruvinel VRN, Zolnikov TR, Obara MT, de Oliveira VTL, Vianna EN, do Santos FSG, de Oliveira KC and Scott JA (2020) Vector-borne diseases in waste pickers in Brasilia, Brazil. Waste Manag 105:223-232.

Cunha WP, Dias ICL, Martins DF and Silva MIS (2012) Perfil de produtores rurais frente às zoonoses e medidas profiláticas de doenças em rebanhos bovinos. Ext Rural 19:93-108.

Curi NHA, Paschoal AMO, Massara RL, Marcelino AP, Ribeiro AA, Passamani M, Demétrio GR and Chiarello AG (2014) Factors associated with the seroprevalence of leishmaniasis in dogs living around Atlantic Forest fragments. PLoS One 9:e104003.

Da Silva MS, Silveira S, Caron VS, Mósena ACS, Weber MN, Cibulski SP, Medeiros AAR, Silva GS, Corbellini LG, Klein $\mathrm{R}$ et al. (2018) Backyard pigs are a reservoir of zoonotic hepatitis E virus in southern Brazil. Trans R Soc Trop Med Hyg 112:14-21.

Das P, Sazzad HMS, Aleem MA, Rahman MZ, Rahman M, Anthony SJ, Lipkin WI, Gurley ES, Luby SP and Openshaw JJ (2019) Hospital-based zoonotic disease surveillance in Bangladesh: design, field data and difficulties. Philos Trans R Soc Lond B Biol Sci 374:20190019.

Davies TJ and Pedersen AB (2008) Phylogeny and geography predict pathogen community similarity in wild primates and humans. Proc Biol Sci 275:1695-1701.

Davis SL (1998) Environmental modulation of the immune system via the endocrine system. Domest Anim Endocrinol 15:283-289. de Araujo J, Thomazelli LM, Henriques DA, Lautenschalager D, Ometto T, Dutra LM, Aires CC, Favorito S and Durigon EL (2012) Detection of hantavirus in bats from remaining rain forest in São Paulo, Brazil. BMC Res Notes 5:690.

de Wit E, van Doremalen N, Falzarano D and Munster VJ (2016) SARS and MERS: recent insights into emerging coronaviruses. Nat Rev Microbiol 14:523-534.

Devi S (2017) Research needed to prevent MERS coronavirus outbreaks. Lancet 389:1502.

Dias AASO, Santos LS, Sabbadini PS, Santos CS, Silva Junior FC, Napoleão F, Nagao PE, Villas-Bôas MHS, Hirata Junior R and Guaraldi ALM (2011) Corynebacterium ulcerans diphtheria: an emerging zoonosis in Brazil and worldwide. Rev Saude Publica 45:1176-1191.

Dolja VV and Koonin EV (2018) Metagenomics reshapes the concepts of RNA virus evolution by revealing extensive horizontal virus transfer. Virus Res 244:36-52.

Dong E, Du H and Gardner L (2020) An interactive web-based dashboard to track COVID-19 in real time. Lancet Infect Dis 20:533-534.

El Bizri HR, Morcatty TQ, Valsecchi J, Mayor P, Ribeiro JES, Vasconcelos Neto CFA, Oliveira JS, Furtado KM, Ferreira UC, Miranda CFS et al. (2020) Urban wild meat consumption and trade in central Amazonia. Conserv Biol 34: 438-448.

Ellwanger JH and Chies JAB (2018) Zoonotic spillover and emerging viral diseases - time to intensify zoonoses surveillance in Brazil. Braz J Infect Dis 22:76-78.

Ellwanger JH and Chies JAB (2019) The triad "dogs, conservation and zoonotic diseases" - An old and still neglected problem in Brazil. Perspect Ecol Conser 17:157-161.

Ellwanger JH, Kaminski VL and Chies JAB (2017) How to detect new viral outbreaks or epidemics? We need to survey the circulation of viruses in humans and other animals using fast, sensible, cheap, and broad-spectrum methodologies. Braz J Infect Dis 21:211-212.

Ellwanger JH, Kaminski VL and Chies JAB (2019) Emerging infectious disease prevention: Where should we invest our resources and efforts? J Infect Public Health 12:313-316.

Ellwanger JH, Kaminski VL, Valverde-Villegas JM, Simon D, Lunge VR and Chies JAB (2018a) Immunogenetic studies of the hepatitis $\mathrm{C}$ virus infection in an era of pan-genotype antiviral therapies - Effective treatment is coming. Infect Genet Evol 66:376-391.

Ellwanger JH, Zambra FMB, Guimarães RL and Chies JAB (2018b) MicroRNA-related polymorphisms in infectious diseases-Tiny changes with a huge impact on viral infections and potential clinical applications. Front Immunol 9:1316.

Ellwanger JH, Kulmann-Leal B, Kaminski VL, Valverde-Villegas JM, da Veiga ABG, Spilki FR, Fearnside PM, Caesar L, Giatti LL, Wallau GL et al. (2020) Beyond diversity loss and climate change: Impacts of Amazon deforestation on infectious diseases and public health. An Acad Bras Cienc 92:e20191375.

Esbérard CEL, Luz JL, Costa LM and Bergallo HG (2014) Bats (Mammalia, Chiroptera) of an urban park in the metropolitan area of Rio de Janeiro, southeastern Brazil. Iheringia, Ser Zool 104:59-69.

Fam BSO, Vargas-Pinilla P, Amorim CEG, Sortica VA and Bortolini MC (2020) ACE2 diversity in placental mammals reveals the evolutionary strategy of SARS-CoV-2. Genet Mol Biol 43:e20200104.

Faria NR, Quick J, Claro IM, Thézé J, de Jesus JG, Giovanetti M, Kraemer MUG, Hill SC, Black A, da Costa AC et al. (2017) Establishment and cryptic transmission of Zika virus in Brazil and the Americas. Nature 546:406-410. 
Faria NR, Rambaut A, Suchard MA, Baele G, Bedford T, Ward MJ, Tatem AJ, Sousa JD, Arinaminpathy N, Pépin J et al. (2014) The early spread and epidemic ignition of HIV-1 in human populations. Science 346:56-61.

Field H, Young P, Yob JM, Mills J, Hall L and Mackenzie J (2001) The natural history of Hendra and Nipah viruses. Microbes Infect 3:307-314.

Figueiredo LTM (2019) Human urban arboviruses can infect wild animals and jump to sylvatic maintenance cycles in South America. Front Cell Infect Microbiol 9:259.

Fonseca RA and Pezzuti JCB (2013) Dietary breadth of the animal protein consumed by riverine communities in the Tapajós National Forest, Brazil. Rev Biol Trop 61:263-272.

Geoghegan JL, Senior AM, Di Giallonardo F and Holmes EC (2016) Virological factors that increase the transmissibility of emerging human viruses. Proc Natl Acad Sci U S A 113:41704175.

Gibb R, Redding DW, Chin KQ, Donnelly CA, Blackburn TM, Newbold T and Jones KE (2020) Zoonotic host diversity increases in human-dominated ecosystems. Nature 584:398402.

Gilbert MTP, Rambaut A, Wlasiuk G, Spira TJ, Pitchenik AE and Worobey M (2007) The emergence of HIV/AIDS in the Americas and beyond. Proc Natl Acad Sci U S A 104:1856618570.

Giles JR, Eby P, Parry H, Peel AJ, Plowright RK, Westcott DA and McCallum H (2018) Environmental drivers of spatiotemporal foraging intensity in fruit bats and implications for Hendra virus ecology. Sci Rep 8:9555.

Glennon EE, Jephcott FL, Restif O and Wood JLN (2019) Estimating undetected Ebola spillovers. PLoS Negl Trop Dis 13:e007428.

Góes LGB, Campos ACA, Carvalho C, Ambar G, Queiroz LH, CruzNeto AP, Munir M and Durigon EL (2016) Genetic diversity of bats coronaviruses in the Atlantic Forest hotspot biome, Brazil. Infect Genet Evol 44:510-513.

Gomes MN, Monteiro AMV, Lewis N, Gonçalves CA and Filho VSN (2010) Landscape risk factors for attacks of vampire bats on cattle in Sao Paulo, Brazil. Prev Vet Med 93:139-146.

Gonçalves-Oliveira J, Rozental T, Guterres A, Teixeira BR, AndradeSilva BE, Costa-Neto SF, Furtado MC, Moratelli R, D'Andrea OS and Lemos ERS (2020) Investigation of Bartonella spp. in brazilian mammals with emphasis on rodents and bats from the Atlantic Forest. Int J Parasitol Parasites Wildl 13:80-89.

Gryseels S, Watts TD, Mpolesha JMK, Larsen BB, Lemey P, Muyembe-Tamfum JJ, Teuwen DE and Worobey M (2020) A near full-length HIV-1 genome from 1966 recovered from formalin-fixed paraffin-embedded tissue. Proc Natl Acad Sci U S A 117:12222-12229.

Guan Y, Zheng BJ, He YQ, Liu XL, Zhuang ZX, Cheung CL, Luo SW, Li PH, Zhang LJ, Guan YJ et al. (2003) Isolation and characterization of viruses related to the SARS coronavirus from animals in southern China. Science 302(5643):276-278.

Guth S, Visher E, Boots M and Brook CE (2019) Host phylogenetic distance drives trends in virus virulence and transmissibility across the animal-human interface. Philos Trans R Soc Lond B Biol Sci 374(1782):20190296.

Hahn BH, Shaw GM, De Cock KM and Sharp PM (2000) AIDS as a zoonosis: scientific and public health implications. Science 287:607-614.

Han BA, Kramer AM and Drake JM (2016) Global patterns of zoonotic disease in mammals. Trends Parasitol 32:565-577.

Hendy A, Hernandez-Acosta E, Valério D, Mendonça C, Costa ER, Júnior JTA, Assunção FP, Scarpassa VM, Gordo M, Fé NF et al. (2020) The vertical stratification of potential bridge vectors of mosquito-borne viruses in a central Amazonian forest bordering Manaus, Brazil. Sci Rep 10:18254.
Hill SC, de Souza R, Thézé J, Claro I, Aguiar RS, Abade L, Santos FCP, Cunha MS, Nogueira JS, Salles FCS et al. (2020) Genomic surveillance of yellow fever virus epizootic in São Paulo, Brazil, 2016 - 2018. PLoS Pathog 16:e1008699.

Himsworth CG, Parsons KL, Jardine C and Patrick DM (2013) Rats, cities, people, and pathogens: a systematic review and narrative synthesis of literature regarding the ecology of ratassociated zoonoses in urban centers. Vector Borne Zoonotic Dis 13:349-359.

Hotez PJ (2014) Ten global "hotspots" for the neglected tropical diseases. PLoS Negl Trop Dis 8:e2496.

Hundal JS, Sodhi SS, Gupta A, Singh J and Chahal US (2016) Awareness, knowledge, and risks of zoonotic diseases among livestock farmers in Punjab. Vet World 9:186-191.

Iversson LB (1980) Aspectos da epidemia de encefalite por arbovírus na região do Vale do Ribeira, S. Paulo, Brasil, no período de 1975 a 1978. Rev Saude Publica 14:9-35.

Jin Y, Yang H, Ji W, Wu W, Chen S, Zhang W and Duan G (2020) Virology, epidemiology, pathogenesis, and control of COVID-19. Viruses 12:E372.

Johnson CJ, Hitchens PL, Evans TS, Goldstein T, Thomas K, Clements A, Joly DO, Wolfe ND, Daszak P, Karesh WB et al. (2015) Spillover and pandemic properties of zoonotic viruses with high host plasticity. Sci Rep 5:14830.

Johnson PTJ and Thieltges DW (2010) Diversity, decoys and the dilution effect: how ecological communities affect disease risk. J Exp Biol 213:961-970.

Jones KE, Patel NG, Levy MA, Storeygard A, Balk D, Gittleman JL and Daszak P (2008) Global trends in emerging infectious diseases. Nature 451:990-993.

Kamada AJ, Pontillo A, Guimarães RL, Loureiro P, Crovella S and Brandão LAC (2014) NLRP3 polymorphism is associated with protection against human T-lymphotropic virus 1 infection. Mem Inst Oswaldo Cruz 109:960-963.

Keesing F, Belden LK, Daszak P, Dobson A, Harvell CD, Holt RD, Hudson P, Jolles A, Jones KE et al. (2010) Impacts of biodiversity on the emergence and transmission of infectious diseases. Nature 468:647-652.

Khalil H, Ecke F, Evander M, Magnusson M and Hörnfeldt B (2016) Declining ecosystem health and the dilution effect. Sci Rep 6:31314.

Klous G, Huss A, Heederik DJJ and Coutinho RA (2016) Humanlivestock contacts and their relationship to transmission of zoonotic pathogens, a systematic review of literature. One Health 2:65-76.

Knetsch CW, Kumar N, Forster SC, Connor TR, Browne HP, Harmanus C, Sanders IM, Harris SR, Turner L, Morris T et al. (2018) Zoonotic transfer of Clostridium difficile harboring antimicrobial resistance between farm animals and humans. J Clin Microbiol 56:e01384-17.

Kovacs JA and Masur H (2000) Prophylaxis against opportunistic infections in patients with human immunodeficiency virus infection. N Engl J Med 342:1416-1429.

Kreitinger JM, Beamer CA and Shepherd DM (2016) Environmental immunology: Lessons learned from exposure to a select panel of immunotoxicants. J Immunol 196:3217-325.

Kurpiers LA, Schulte-Herbrüggen B, Ejotre I and Reeder DM (2016) Bushmeat and emerging infectious diseases: lessons from Africa. In: Angelici F (ed) Problematic Wildlife: A CrossDisciplinary Approach. Springer, Cham pp 507-551.

Lam TT, Jia N, Zhang YW, Shum MH, Jiang JF, Zhu HC, Tong YG, Shi YX, Ni XB, Liao YS et al. (2020) Identifying SARS$\mathrm{CoV}-2$ related coronaviruses in Malayan pangolins. Nature 583:282-285.

Laporta GZ, Ribeiro MC, Ramos DG and Sallum MA(2012) Spatial distribution of arboviral mosquito vectors (Diptera, Culicidae) 
in Vale do Ribeira in the South-eastern Brazilian Atlantic Forest. Cad Saude Publica 28:229-238.

Latinne A, Hu B, Olival KJ, Zhu G, Zhang L, Li H, Chmura AA, Field HE, Zambrana-Torrelio C, Epstein JH et al. (2020) Origin and cross-species transmission of bat coronaviruses in China. Nat Commun 11:4235.

Lee A (2020) Wuhan novel coronavirus (COVID-19): why global control is challenging? Public Health 179:A1-A2.

Lee CT, Slavinski S, Schiff C, Merlino M, Daskalakis D, Liu D, Rakeman JL, Misener M, Thompson C, Leung YL et al. (2017) Outbreak of influenza A(H7N2) among cats in an animal shelter with cat-to-human transmission-New York city, 2016. Clin Infect Dis 65:1927-1929.

Li X, Giorgi EE, Marichannegowda MH, Foley B, Xiao C, Kong XP, Chen Y, Gnanakaran S, Korber B and Gao F (2020) Emergence of SARS-CoV-2 through recombination and strong purifying selection. Sci Adv 6:eabb9153.

Liu SL (2020) Curb spread of virus emerging in China. Nature 577:472.

Liu Y and Weng Q (2014) Fauna in decline: plight of the pangolin. Science 345:884.

Lo MY, Ngan WY, Tsun SM, Hsing HL, Lau KT, Hung HP, Chan SL, Lai YY, Yao Y, Pu Y et al. (2019) A field study into Hong Kong's wet markets: Raised questions into the hygienic maintenance of meat contact surfaces and the dissemination of microorganisms associated with nosocomial infections. Front Microbiol 10:2618.

LoGiudice K, Ostfeld RS, Schmidt KA and Keesing F (2003) The ecology of infectious disease: effects of host diversity and community composition on Lyme disease risk. Proc Natl Acad Sci U S A 100:567-571.

Loh EH, Zambrana-Torrelio C, Olival KJ, Bogich TL, Johnson CK, Mazet JA, Karesh W and Daszak P (2015) Targeting transmission pathways for emerging zoonotic disease surveillance and control. Vector Borne Zoonotic Dis 15:432437.

Lopes OS, Sacchetta LA, Coimbra TLM, Pinto GH and Glasser CM (1978) Emergence of a new arbovirus disease in Brazil. II. Epidemiologic studies on 1975 epidemic. Am J Epidemiol 108:394-401.

Lu G, Wang Q and Gao GF (2015) Bat-to-human: spike features determining 'host jump' of coronaviruses SARS-CoV, MERS$\mathrm{CoV}$, and beyond. Trends Microbiol 23:468-478.

Mahapatra M, Sayalel K, Muniraju M, Eblate E, Fyumagwa R, Shilinde L, Mdaki M, Keyyu J, Parida S and Kock R (2015) Spillover of Peste des petits ruminants virus from domestic to wild ruminants in the Serengeti ecosystem, Tanzania. Emerg Infect Dis 21:2230-2234.

Maioli V, Belharte S, Kropf MS and Callado CH (2020) Timber exploitation in colonial Brazil: A historical perspective of the Atlantic Forest. HALAC 10:46-73.

Mallapaty S (2020) Where did COVID come from? WHO investigation begins but faces challenges. Nature 587:341-342.

Martin G, Webb RJ, Chen C, Plowright RK and Skerratt LF (2017) Microclimates might limit indirect spillover of the bat borne zoonotic Hendra virus. Microb Ecol 74:106-115.

Martin G, Yanez-Arenas C, Plowright RK, Chen C, Roberts B and Skerratt LF (2018) Hendra virus spillover is a bimodal system driven by climatic factors. EcoHealth 15:526-542.

Marty AM and Jones MK (2020) The novel Coronavirus (SARSCoV-2) is a one health issue. One Health 9:100123.

Matzaraki V, Kumar V, Wijmenga C and Zhernakova A (2017) The MHC locus and genetic susceptibility to autoimmune and infectious diseases. Genome Biol 18:76.
McDonald SM, Nelson MI, Turner PE and Patton JT (2016) Reassortment in segmented RNA viruses: mechanisms and outcomes. Nat Rev Microbiol 14:448-460.

Mendoza H, Rubio AV, García-Peña GE, Suzán G and Simonetti JA (2020) Does land-use change increase the abundance of zoonotic reservoirs? Rodents say yes. Eur J Wildl Res 66:6.

Mickleburgh SP, Hutson AM and Racey PS (2002) A review of the global conservation status of bats. Oryx 36:18-34.

Mittal M, Chakravarti S, Sharma V, Sanjeeth BS, Churamani CP and Kanwar NS (2014) Evidence of presence of Mycobacterium tuberculosis in bovine tissue samples by multiplex PCR: possible relevance to reverse zoonosis. Transbound Emerg 61:97-104.

Mollentze N and Streicker DG (2020) Viral zoonotic risk is homogenous among taxonomic orders of mammalian and avian reservoir hosts. Proc Natl Acad Sci U S A 117:9423-9430.

Morand S (2020) Emerging diseases, livestock expansion and biodiversity loss are positively related at global scale. Biol Conserv 248:108707.

Morse SS, Mazet JAK, Woolhouse M, Parrish CR, Carroll D, Karesh WB, Zambrana-Torrelio C, Lipkin WI and Daszak P (2012) Prediction and prevention of the next pandemic zoonosis. Lancet 380:1956-1965.

Mukherjee S, Karmakar S and Babu SPS (2016) TLR2 and TLR4 mediated host immune responses in major infectious diseases: a review. Braz J Infect Dis 20:193-204.

Musoke J, Hlokwe T, Marcotty T, du Plessis BJ and Michel AL (2015) Spillover of Mycobacterium bovis from wildlife to livestock, South Africa. Emerg Infect Dis 21:448-451.

Nelson MI and Vincent AL (2015) Reverse zoonosis of influenza to swine: new perspectives on the human-animal interface. Trends Microbiol 23:142-153.

Neto OA (2018) O Brasil no mercado mundial de carne bovina: análise da competitividade da produção e da logística de exportação brasileira. Ateliê Geogr 12:183-204.

Neves MAO, Sousa Júnior AS, de Camargo DS, Lobo PS, Bandeira RS, Soares LS and Mascarenhas JDP (2020) Characterization of rotavirus possessing a DS-1-like VP3 gene from pigs in Brazil: Evidence for zooanthroponotic transmission. Infect Genet Evol 79:104151.

Newbold T, Hudson LN, Hill SLL, Contu S, Lysenko I, Senior RA, Börger L, Bennett DJ, Choimes A, Collen B et al. (2015) Global effects of land use on local terrestrial biodiversity. Nature 520:45-50.

Ng OW and Tan YJ (2017) Understanding bat SARS-like coronaviruses for the preparation of future coronavirus outbreaks - Implications for coronavirus vaccine development. Hum Vaccin Immunother 13:186-189.

Nichol ST, Arikawa J and Kawaoka Y (2000) Emerging viral diseases. Proc Natl Acad Sci U S A 97:12411-12412.

Nunes H, Rocha FL and Cordeiro-Estrela P (2017) Bats in urban areas of Brazil: roosts, food resources and parasites in disturbed environments. Urban Ecosyst 20:953-969.

Nunes MRT, Faria NR, de Vasconcelos JM, Golding N, Kraemer MUG, de Oliveira LF, Azevedo RSS, da Silva DEA, da Silva EVP, da Silva SP et al. (2015) Emergence and potential for spread of Chikungunya virus in Brazil. BMC Med 13:102.

O'Shea TJ, Cryan PM, Cunningham AA, Fooks AR, Hayman DTS, Luis AD, Peel AJ, Plowright RK and Wood JL (2014) Bat flight and zoonotic viruses. Emerg Infect Dis 20:741-745.

Olival KJ (2016) To cull, or not to cull, bat is the question. EcoHealth 13:6-8.

Olival KJ, Hosseini PR, Zambrana-Torrelio C, Ross N, Bogich TL and Daszak P (2017) Host and viral traits predict zoonotic spillover from mammals. Nature 546:646-650. 
Olival KJ, Cryan PM, Amman BR, Baric RS, Blehert DS, Brook CE, Calisher CH, Castle KT, Coleman JTH, Daszak P et al. (2020) Possibility for reverse zoonotic transmission of SARSCoV-2 to free-ranging wildlife: A case study of bats. PLoS Pathog 16:e1008758.

Oliveira DB, Assis FL, Ferreira PCP, Bonjardim CA, de Souza Trindade G, Kroon EG and Abrahão JS (2013) Group 1 Vaccinia virus zoonotic outbreak in Maranhao State, Brazil. Am J Trop Med Hyg 89:1142-1145.

Ostfeld RS (2017) Biodiversity loss and the ecology of infectious disease. Lancet Planet Health 1:e2-e3.

Ostfeld RS and Keesing F (2020) Species that can make us ill thrive in human habitats. Nature 584:346-347.

Parrish CR, Holmes EC, Morens DM, Park EC, Burke DS, Calisher CH, Laughlin CA, Saif LJ and Daszak P (2008) Cross-species virus transmission and the emergence of new epidemic diseases. Microbiol Mol Biol Rev 72:457-470.

Pereira MJR, Bernard E and Aguiar LMS (2020) Bats and COVID-19: villains or victims? Biota Neotrop 20:e20201055.

Peres CA (2000) Effects of subsistence hunting on vertebrate community structure in Amazonian forests. Conserv Biol $14: 240-253$

Pigott DM, Golding N, Mylne A, Huang Z, Henry AJ, Weiss DJ, Brady OJ, Kraemer MUG, Smith DL, Moyes CL et al. (2014) Mapping the zoonotic niche of Ebola virus disease in Africa. Elife 3:e04395.

Plowright RK, Parrish CR, McCallum H, Hudson PJ, Ko AI, Graham AL and Lloyd-Smith JO (2017) Pathways to zoonotic spillover. Nat Rev Microbiol 15:502-510.

Poirot E, Levine MZ, Russell K, Stewart RJ, Pompey JM, Chiu S, Fry AM, Gross L, Havers FP, Li ZN et al. (2019) Detection of avian influenza $\mathrm{A}(\mathrm{H} 7 \mathrm{~N} 2)$ virus infection among animal shelter workers using a novel serological approach-New York City, 2016-2017. J Infect Dis 219:1688-1696.

Possas C, Lourenço-de-Oliveira R, Tauil PL, Pinheiro FP, Pissinatti A, Cunha RVD, Freire M, Martins RM and Homma A (2018) Yellow fever outbreak in Brazil: the puzzle of rapid viral spread and challenges for immunisation. Mem Inst Oswaldo Cruz 113:e180278.

Pulliam JR and Dushoff J (2009) Ability to replicate in the cytoplasm predicts zoonotic transmission of livestock viruses. J Infect Dis 199:565-568.

Quintana-Murci L, Alcaïs A, Abel L and Casanova JL (2007) Immunology in natura: clinical, epidemiological and evolutionary genetics of infectious diseases. Nat Immunol 8:1165-1171.

Rabaan AA (2017) Middle East respiratory syndrome coronavirus: five years later. Expert Rev Respir Med 11:901-912.

Rabello RF, Bonelli RR, Penna BA, Albuquerque JP, Souza RM and Cerqueira AMF (2020) Antimicrobial resistance in farm animals in Brazil: An update overview. Animals (Basel) 10:552.

Reperant LA, Brown IH, Haenen OL, de Jong MD, Osterhaus ADME, Papa A, Rimstad E, Valarcher JF and Kuiken T (2016) Companion animals as a source of viruses for human beings and food production animals. J Comp Pathol 155:S41-S53.

Ribeiro MC, Martensen AC, Metzger JP, Tabarelli M, Scarano F and Fortin MJ (2011) The Brazilian Atlantic Forest: A Shrinking Biodiversity Hotspot. In: Zachos F and Habel J (eds) Biodiversity Hotspots. Springer, Berlin, Heidelberg, pp 405-434.

Rodrigues CM (2017) O círculo vicioso da negligência da leptospirose no Brasil. Rev Inst Adolfo Lutz 76:e1729.

Rodriguez-Morales AJ, Bonilla-Aldana DK, Balbin-Ramon GJ, Rabaan AA, Sah R, Paniz-Mondolfi A, Pagliano P and Esposito S (2020) History is repeating itself: Probable zoonotic spillover as the cause of the 2019 novel coronavirus epidemic. Infez Med 28:3-5.

Rohr JR, Barrett CB, Civitello DJ, Craft ME, Delius B, DeLeo GA, Hudson PJ, Jouanard N, Nguyen KH, Ostfeld RS et al. (2019) Emerging human infectious diseases and the links to global food production. Nat Sustain 2:445-456.

Rossi F (2011) The challenges of antimicrobial resistance in Brazil. Clin Infect Dis 52:1138-1143

Rozental T, Ferreira MS, Guterres A, Mares-Guia MA, Teixeira BR, Gonçalves J, Bonvicino CR, D'Andrea OS and de Lemos ERS (2017) Zoonotic pathogens in Atlantic Forest wild rodents in Brazil: Bartonella and Coxiella infections. Acta Trop 168:64-73.

Rulli MC, Santini M, Hayman DTS and D'Odorico P (2017) The nexus between forest fragmentation in Africa and Ebola virus disease outbreaks. Sci Rep 7:41613.

Russo D and Ancillotto L (2015) Sensitivity of bats to urbanization: a review. Mamm Biol 80:205-212.

Saéz AM, Weiss S, Nowak K, Lapeyre V, Zimmermann F, Düx A, Kühl HS, Kaba M, Regnaut S, Merkel K et al. (2015) Investigating the zoonotic origin of the West African Ebola epidemic. EMBO Mol Med 7:17-23.

Sanches A, Tokumoto PM, Peres WAM, Nunes FL, Gotardi MST, Carvalho CS, Pelizzon C, Godoi TG and Galetti M (2012) Illegal hunting cases detected with molecular forensics in Brazil. Investig Genet 3:17.

Schmidt JP, Park AW, Kramer AM, Han BA, Alexander LW and Drake JM (2017) Spatiotemporal fluctuations and triggers of Ebola virus spillover. Emerg Infect Dis 23:415-422.

Schmidt KA and Ostfeld RS (2001) Biodiversity and the dilution effect in disease ecology. Ecology 82:609-619.

Sevá AP, Pena HFJ, Nava A, Sousa AO, Holsback L and Soares RM (2018) Endoparasites in domestic animals surrounding an Atlantic Forest remnant, in São Paulo State, Brazil. Rev Bras Parasitol Vet 27:13-19.

Sharp PM and Hahn BH (2011) Origins of HIV and the AIDS pandemic. Cold Spring Harb Perspect Med 1:a006841.

Shi Y, Wu Y, Zhang W, Qi J and Gao GF (2014) Enabling the 'host jump': structural determinants of receptor-binding specificity in influenza A viruses. Nat Rev Microbiol 12:822-831.

Shikanai-Yasuda MA, Mendes RP, Colombo AL, Queiroz-Telles F, Kono ASG, Paniago AMM, Nathan A, Valle ACFD, Bagagli $\mathrm{E}$, Benard G et al. (2017) Brazilian guidelines for the clinical management of paracoccidioidomycosis. Rev Soc Bras Med Trop 50:715-740.

Sit THC, Brackman CJ, Ip SM, Tam KWS, Law PYT, To EMW, Yu VYT, Sims LD, Tsang DNC, Chu DKW et al. (2020) Infection of dogs with SARS-CoV-2. Nature 586:776-778.

Souto WMS, Barboza RRD, Fernandes-Ferreira H, Júnior AJCM, Monteiro JM, Abi-Chacra ÉA and Alves RRN (2018) Zootherapeutic uses of wildmeat and associated products in the semiarid region of Brazil: general aspects and challenges for conservation. J Ethnobiol Ethnomed 14:60.

Taubenberger JK and Morens DM (2006) 1918 Influenza: the mother of all pandemics. Emerg Infect Dis 12:15-22.

Taylor LH, Latham SM and Woolhouse ME (2001) Risk factors for human disease emergence. Philos Trans R Soc Lond B Biol Sci 356:983-989.

Tebug SF, Kamga-Waladjo AR, Ema PJN, Muyeneza C, Kane O, Seck A, Ly MT and Lo M (2015) Cattle farmer awareness and behavior regarding prevention of zoonotic disease transmission in Senegal. J Agromedicine 20:217-224.

Thompson RC (2013) Parasite zoonoses and wildlife: One Health, spillover and human activity. Int J Parasitol 43:1079-1088.

Tomley FM and Shirley MW (2009) Livestock infectious diseases and zoonoses. Philos Trans R Soc Lond B Biol Sci 364:2637-2642. 
Torres PC, Morsello C, Parry L and Pardini R (2016) Who cares about forests and why? Individual values attributed to forests in a post-frontier region in Amazonia. PLoS One 11:e167691.

van Vliet N, Quiceno-Mesa MP, Cruz-Antia D, de Aquino LJN, Moreno J and Nasi R (2014) The uncovered volumes of bushmeat commercialized in the Amazonian trifrontier between Colombia, Peru \& Brazil. Ethnobio Conserv 3:7.

Ventura DFL, Ribeiro H, di Giulio GMD, Jaime PC, Nunes J, Bógus CM, Antunes JLF and Waldman EA (2020) Challenges of the COVID-19 pandemic: for a Brazilian research agenda in global health and sustainability. Cad Saude Publica 36:e00040620.

Vicente CR (2020) Is Brazil prepared for the new era of infectious disease epidemics? Rev Soc Bras Med Trop 53:e20200218.

Vieira AS, D'Andrea PS, Vilela RDV, Loretto D, Jaeger LH, CarvalhoCosta FA and Lilenbaum W (2019) Pathogenic Leptospira species are widely disseminated among small mammals in Atlantic Forest biome. Transbound Emerg Dis 66:1195-1201.

Walker JW, Han BA, Ott IM and Drake JM (2018) Transmissibility of emerging viral zoonoses. PLoS One 13:e206926.

Wang L, Zhang W, Du Y and Wang Z (2020) Investigation and analysis on the concept and behavior characteristics of eating game in mainland China. E3S Web Conf (ICGEC 2020) 206:01006

Wang LF and Anderson DE (2019) Viruses in bats and potential spillover to animals and humans. Curr Opin Virol 34:79-89.

Warren CJ and Sawyer SL (2019) How host genetics dictates successful viral zoonosis. PLoS Biol 17:e3000217.

Washburne AD, Crowley DE, Becker DJ, Olival KJ, Taylor M, Munster VJ and Plowright RK (2018) Taxonomic patterns in the zoonotic potential of mammalian viruses. PeerJ 6:e5979.

Wasik BR, de Wit E, Munster V, Lloyd-Smith JO, Martinez-Sobrido L and Parrish CR (2019) Onward transmission of viruses: how do viruses emerge to cause epidemics after spillover? Philos Trans R Soc Lond B Biol Sci 374:20190017.

Wassenaar TM and Zou Y (2020) 2019_nCoV/SARS-CoV-2: rapid classification of betacoronaviruses and identification of Traditional Chinese Medicine as potential origin of zoonotic coronaviruses. Lett Appl Microbiol 70:342-348.

Weaver SC (2013) Urbanization and geographic expansion of zoonotic arboviral diseases: mechanisms and potential strategies for prevention. Trends Microbiol 21:360-363.

Wells K and Clark NJ (2019) Host specificity in variable environments. Trends Parasitol 35:452-465.

Wilke ABB, Beier JC and Benelli G (2019) Complexity of the relationship between global warming and urbanization an obscure future for predicting increases in vector-borne infectious diseases. Curr Opin Insect Sci 35:1-9.

Wójtowicz A, Bibert S, Taffé P, Bernasconi E, Furrer H, Günthard HF, Hoffmann M, Osthoff M, Cavassini M, Bochud PY et al. (2019) IL-4 polymorphism influences susceptibility to Pneumocystis jirovecii pneumonia in HIV-positive patients. AIDS 33:1719-1727.

Wolfe ND, Daszak P, Kilpatrick AM and Burke DS (2005) Bushmeat hunting, deforestation, and prediction of zoonoses emergence. Emerg Infect Dis 11:1822-1827.

Wolfe ND, Dunavan CP and Diamond J (2007) Origins of major human infectious diseases. Nature 447:279-283.

Woolhouse MEJ and Gowtage-Sequeria S (2005) Host range and emerging and reemerging pathogens. Emerg Infect Dis 11:1842-1847.

Woolhouse M, Ward M, van Bunnik B and Farrar J (2015)Antimicrobial resistance in humans, livestock and the wider environment. Philos Trans R Soc Lond B Biol Sci 370:20140083.
Worobey M, Watts TD, McKay RA, Suchard MA, Granade T, Teuwen DE, Koblin BA, Heneine W, Lemey P and Jaffe HW (2016) 1970s and 'Patient 0' HIV-1 genomes illuminate early HIV/ AIDS history in North America. Nature 539:98-101.

Wu F, Zhao S, Yu B, Chen YM, Wang W, Song ZG, Hu Y, Tao ZW, Tian JH, Pei YY et al. (2020) A new coronavirus associated with human respiratory disease in China. Nature 579:265-269.

Yang Q, Chen J, BAI ZL, Deng XB and Liu ZQ (2000) [Trade of wild animals and plants in China-Laos border areas: status and suggestion for effective management]. Biodiv Sci 8: 284-296.

Xiao K, Zhai J, Feng Y, Zhou N, Zhang X, Zou JJ, Li N, Guo Y, Li X, Shen X et al. (2020) Isolation of SARS-CoV-2-related coronavirus from Malayan pangolins. Nature 583:286-289.

Ximenes MFFM, Galvão JMA, Inacio CLS, Silva VPM, Pereira RLN, Pinheiro MPG, Silva MMM and Gomes CES (2020) Arbovirus expansion: New species of culicids infected by the Chikungunya virus in an urban park of Brazil. Acta Trop 209:105538.

Zhang T, Wu Q and Zhang Z (2020) Probable pangolin origin of SARS-CoV-2 associated with the COVID-19 outbreak. Curr Biol 30:1346-1351.

Zhang YZ and Holmes EC (2020) A genomic perspective on the origin and emergence of SARS-CoV-2. Cell 181:223-227.

Zhong S, Crang M and Zeng G (2020) Constructing freshness: the vitality of wet markets in urban China. Agric Hum Values 37:175-185.

Zhou H, Chen X, Hu T, Li J, Song H, Liu Y, Wang P, Liu D, Yang J, Holmes EC, Hughes AC et al. (2020b). A novel bat coronavirus closely related to SARS-CoV-2 contains natural insertions at the S1/S2 cleavage site of the spike protein. Curr Biol 30:2196-2203.

Zhou P, Yang XL, Wang XG, Hu B, Zhang L, Zhang W, Si HR, Zhu Y, Li B, Huang CL et al. (2020a) A pneumonia outbreak associated with a new coronavirus of probable bat origin. Nature 579:270-273.

Zhou ZM, Zhou Y, Newman C and Macdonald DW (2014) Scaling up pangolin protection in China. Front Ecol Environ 12:97-98.

\section{Internet Resources}

Cyranoski D (2020a) New virus identified as likely cause of mystery illness in China, https://www.nature.com/articles/d41586-02000020-9 (accessed 24 April 2020).

Cyranoski D (2020b) New virus surging in Asia rattles scientists, https://www.nature.com/articles/d41586-020-00129-x (accessed 24 April 2020).

de Jesus JG, Sacchi C, Claro I, Salles F, Manulli E, da Silva D, de Paiva TM, Pinho M, Afonso AMS, Mathias A et al. (2020) First cases of coronavirus disease (COVID-19) in Brazil, South America (2 genomes, 3rd March 2020), http://virological. org/t/first-cases-of-coronavirus-disease-covid-19-in-brazilsouth-america-2-genomes-3rd-march-2020/409 (accessed 2 May 2020).

Johns Hopkins University (2020) COVID-19 Dashboard by the Center for Systems Science and Engineering (CSSE) at Johns Hopkins University, https://coronavirus.jhu.edu/map.html (accessed 10 December 2020).

\section{Associate Editor: Diogo Meyer}

License information: This is an open-access article distributed under the terms of the Creative Commons Attribution License (type CC-BY), which permits unrestricted use, distribution and reproduction in any medium, provided the original article is properly cited. 